University of Wollongong

Research Online

Faculty of Business - Papers (Archive)

Faculty of Business and Law

2016

To what extent did the economic stimulus package influence bank lending and corporate investment decisions? Evidence from China

Qigui Liu

Zhejiang University, qigui@uow.edu.au

Xiaofei Pan

University of Wollongong, xpan@uow.edu.au

Gary G. Tian

Deakin University, gtian@uow.edu.au

Follow this and additional works at: https://ro.uow.edu.au/buspapers

Part of the Business Commons

Research Online is the open access institutional repository for the University of Wollongong. For further information contact the UOW Library: research-pubs@uow.edu.au 


\title{
To what extent did the economic stimulus package influence bank lending and corporate investment decisions? Evidence from China
}

\author{
Abstract \\ Using a panel of Chinese firms over the period 2003-2013, we show that, from the supply-side \\ perspective, as a result of the implementation of the economic stimulus package in China, state-owned \\ enterprises (SOEs) received more bank loans and invested more than non-SOEs. We further find that after \\ the implementation of the economic stimulus package, bank lending became less responsive to firm \\ profitability, and firm investments became less responsive to investment opportunities for SOEs, non- \\ SOEs from favoured industries and regions, and non-SOEs with political connections. Overall, our findings \\ support the view that the stimulus package and the associated increase in bank loan supply in China \\ resulted in more resources being allocated to SOEs.

\section{Disciplines} \\ Business

\section{Publication Details} \\ Liu, Q., Pan, X. \& Tian, G. Gang. (2016). To what extent did the economic stimulus package influence bank \\ lending and corporate investment decisions? Evidence from China. Journal of Banking and Finance, In \\ press 1-18.
}




\title{
To what extent did the economic stimulus package influence bank lending and corporate investment decisions? Evidence from China
}

\begin{abstract}
Using a panel of Chinese firms over the period 2003-2013, we show that, from the supply-side perspective, as a result of the implementation of the economic stimulus package in China, state-owned enterprises (SOEs) received more bank loans and invested more than non-SOEs. We further find that after the implementation of the economic stimulus package, bank lending became less responsive to firm profitability and firm investments became less responsive to investment opportunities for SOEs, non-SOEs from favoured industries and regions, and non-SOEs with political connections. Overall, our findings support the view that the stimulus package and the associated increase in bank loan supply in China resulted in more resources being allocated to SOEs.
\end{abstract}

Key words: Economic stimulus package, bank loan supply, bank lending, investment decisions, SOEs

JEL: E5, G18, G34 


\section{Introduction}

Major countries that suffered during the recent global financial crisis have launched economic stimulus packages whose main purpose is to restore economic growth ${ }^{1}$. Following Keynesian economic theory, the aim of these economic stimulus packages is to encourage firms to increase investment behaviour, and thus expansionary monetary policy is usually implemented by the monetary authority, which results in a significant increase of bank loan supply in the supply side. However, literature on the effectiveness of the economic stimulus package and the associated expansionary monetary policy mainly focuses on their effect on the macro-economy, such as GDP and employment (Cai et al., 2010; Deng et al., 2014); it is still a controversial issue whether and how the micro-economy is influenced by those stimulus packages, particularly as there is still no evidence about whether and how bank lending and firm investment decisions changed following the expansionary monetary policy. This issue is important because it has been observed that the stimulus package boosted economic growth, but it is unknown whether the growth is sound and sustainable. One way of testing this is to examine whether the increased bank loan supply is allocated to different types of firms fairly and how these firms make their investment decisions following the implementation of the stimulus package. Compared to mature markets whose stimulus package is usually market-oriented, with well-designed mechanisms to guarantee its implementation, the stimulus package in emerging markets may be more governmentoriented, especially in China, where the government still controls a large number of firms and the banking system, which raises the issue of whether Chinese state-owned enterprises (SOEs) and non-state-owned enterprises (non-SOEs) have equal access to the increased bank loan supply and investment opportunities. The investment decisions made by Chinese firms following the implementation of the stimulus package, and the excess capacity problem caused by these investments, have attracted increasing media attention recently ${ }^{2}$, but there is still a lack of empirical evidence at the firm level to support this argument. This study aims to fill this gap by providing fresh evidence on this issue using a sample of Chinese listed firms.

The effectiveness of bank lending through the government-owned banking system has been widely documented in the literature. Though some studies support the political view by claiming that the lending behaviour and credit allocation of government lending may be

\footnotetext{
${ }^{1}$ For example, the US government announced a $\$ 700$ billion stimulus package in 2008 and bailed out financially distressed financial institutions. The Japanese government announced a first round stimulus package in 2010 of \$915 billion Japanese yen and a second round stimulus package \$880 billion Japanese yen in 2012. Other countries also implemented their respectively stimulus packages, including Germany and France.

${ }^{2}$ See http://www.businessinsider.com.au/chinas-excess-capacity-problem-2013-6
} 
distorted with low efficiency due to political interventions (Dinc, 2005; Khwaja and Mian, 2005; Sapienza, 2004), others argue that government lending can cure market failure and improve welfare by providing more capital (Bebchuk and Goldstein, 2011). Empirical evidence suggests that the beneficial effects of government bank lending can be valuable during periods of financial crisis (Giannetti and Simonov, 2009; Tong and Wei, 2012; Chen et al., 2014; Lin et al., 2014). All of these studies, though focusing on different aspects, explicitly mention that the government-owned banking system does have an influence on bank lending and firm investment activities because the government is able to control the bank loan supply better under this system.

Meanwhile, another strand of literature has noticed and explored the relevance of bank loan supply shocks for firms' financing and investment decisions, which depend on firms' ability to access external finance. For example, Leary (2009) provides evidence that following an expansion (contraction) of bank loan supply, the bank loan ratio of small, bankdependent firms significantly increases (decreases) relative to that of large, less bankdependent firms, because small, bank-dependent firms are less likely to switch between public and private debt markets. Lemmon and Roberts (2010) show that net debt issuances decline significantly following contraction in the supply of bank credit. Shen et al. (2014) find that the economic stimulus package in China leads to better access to bank loans for large and SOEs relative to small and private firms. In addition, existing evidence also shows that shifts in bank loan supply helps to determine corporate investment, depending on firms' availability of alternative external finance (Kashyap et al., 1993). Duchin et al. (2010) find that, faced with tighter monetary policy, which reduces the overall bank loan supply, investment will be hampered for firms which lack sufficient capital to fund all profitable investment opportunities, and this is more pronounced for bank-dependent firms. Lemmon and Roberts (2010) present similar findings that loan supply contraction leads to significant decline in net investment for below-investment-grade firms.

Though these studies explicitly suggest that expansion (contraction) of bank loan supply is associated with more (less) bank loan access and corporate investment, the question of whether and how such bank loan supply shock influences bank lending and corporate investment decisions in emerging markets remains unknown. The focus of this study, therefore, is to shed light on this issue to gain an understanding of how bank loan supply shock, resulting from the Chinese economic stimulus package, influences bank lending and firm investment decisions. 
The Chinese capital market and credit supply expansion provide an excellent environment which cannot be replicated in other countries, such as the US, for the following reasons: first, bank loans in China are almost the only external financing resource for firms, due to the immature non-bank financing market (Firth et al., 2008; Shen et al., 2014). Thus, firms in China are more bank-dependent, which makes them much more sensitive to changes in bank loan supply and enables us to examine the influence of bank loan supply shock with less concern for endogeneity issues. However, in developed countries such as the US, firms are able to switch between the public and private debt markets, which makes examination of the effect of bank loan supply shock more difficult.

Second, the banking system in China is mostly controlled by the government, and that is why most bank loans for SOEs are secured, based on economic and political considerations rather than pure commercial judgement. In this sense, relative to non-SOEs, SOEs in China are more bank-dependent, and thus will be affected more profoundly by changes in bank loan supply. Therefore, following an expansion of bank loan supply, access to bank loans for SOEs will increase significantly relative to non-SOEs, regardless of their profitability or creditworthiness. Once SOEs receive more bank loans, which is related to the stimulus package, they invest more, under the pressure of political objectives, irrespective of whether they have profitable investment opportunities or not.

Consistent with our predictions, we find that both SOEs and non-SOEs increase their bank borrowings significantly following the economic stimulus package. We also find that the economic stimulus package results in a weaker connection between newly granted bank loans and firm profitability. Additionally, as more bank loans are available, firms are more likely to be involved in investment activities and face a weaker relationship between investment growth and changes in investment opportunities. All the above phenomena are significant in SOEs but not in non-SOEs. As the change in debt financing may also reflect firms' demand for debt, we also follow Faulkender and Petersen (2006) and Lemmon and Roberts (2010) to control for firms' demand side forces and our findings remain the same. Our additional analysis further reveals that the influence of the economic stimulus package is stronger for non-SOEs from government-favoured industries and regions, and for those with political connections, while the influence of the economic stimulus package is stronger for SOEs from higher corrupt regions and those controlled by local governments. From the perspective of lending institutions, we find that government-owned banks (the big five banks and three policy banks) and joint-equity banks increase their lending significantly, while foreign banks and non-state owned banks reduce their lending following the economic 
stimulus package. We also find that the responsiveness of bank lending to firm profitability becomes weaker for government-owned banks and joint-equity banks following the economic stimulus package. All our above results are robust to a series of further tests that address the endogeneity issue or use alternative measurements of key variables.

Our study contributes to the existing literature in several ways. First, as far as we know, this paper is the first to explore the financial implications of the economic stimulus package and the associated change in monetary policy for bank lending and firm investment decisions in an emerging market. We provide evidence that the stimulus package helps the economy recover from financial tsunami by encouraging banks to lend and firms to invest, but it weakens the relationship between bank lending and firm profitability, and between firm investment and investment opportunities. Overall, our results imply that investment by nonSOEs is crowded out by investment by SOEs, which is backed by the government following the implementation of the stimulus package.

Secondly, we contribute to the literature on the impact of government intervention on corporate policy. Literature has documented that SOEs usually have advantage in obtaining bank loans and they invest less efficiently (Shleifer and Vishny, 1994; Dewenter and Malatesta, 2001; Brandt and Li, 2003; Cull et al., 2009; Li et al., 2009; Firth et al., 2009; Chen et al., 2011), while it is also widely documented that politically connected executives facilitate firms' accessing of bank loans (Agrawal and Knoeber, 2001; Brandt and Li, 2003; Cull et al., 2009; Li et al., 2009; Firth et al., 2009; Khwaja and Mian, 2005; Faccio, 2006). We complement these studies by using the stimulus package as an exogenous shock, and revealing a dynamic change of bank loan financing and investment policy in the connected firms in comparison with non-connected firms when the monetary policy changes.

Thirdly, our study is related to the literature on direct government lending through the state-owned banking system during the period of the financial crisis. Existing evidence from an international study suggests that direct capital infusion by government corrects the inefficiency of credit market freezes (Chen et al., 2014), and thus has a beneficial effect at the firm level, such as increased stock prices (Tong and Wei, 2012), and more investments (Giannetti and Simonov, 2009; Lin et al., 2014). Our study shows that, compared to other types of banks, the lending decisions of state-owned banks are more sensitive to changes of monetary policy. Our study also complements the literature on the impact of government ownership on bank lending behaviour. Sapienza (2004) finds that in Italy state-owned banks favour large firms and firms located in depressed areas, while our study documents that stateowned banks lend primarily to SOEs in China and bank lending is less responsive to firm 
profitability. We believe that the evidence we present constitutes a useful extension to the literature, because a government-controlled banking system is a common phenomenon in emerging markets.

The remainder of the paper is organised as follows. Section 2 introduces the economic stimulus package implemented by the Chinese government and develops our hypotheses. Section 3 describes the sample and methodology. Section 4 presents the empirical results and discussions. Section 5 concludes.

\section{Background and hypothesis development}

\subsection{Economic stimulus package in China}

The global financial crisis has hit China hard, and induced the slowdown in the domestic economy in the second half of 2008. In response to the financial crisis, the Chinese government announced an economic stimulus package of four trillion RMB (about \$586 billion), which accounts for $12.5 \%$ of total GDP in 2008, spending from the fourth quarter 2008 through to the end of 2010. The stimulus package, which increases investment spending, was officially announced on $5^{\text {th }}$ November 2008. Of the total four trillion plan, the central government directly funded 1.18 trillion of the investment, which is $30 \%$ of the overall program, and the rest was funded by local governments and a loosening of monetary policy to provide bank credit to support investment (Naughton, 2009). In reality, the disbursement of central government stimulus spending includes the following six tranches: 108 billion in the fourth quarter of 2008130 billion, 70 billion, 80 billion and 223.8 billion respectively in the first to fourth quarters of 2009, and 992.7 billion in 2010. Altogether, the central government input into to the stimulus totalled 1.6 trillion, which is more than what was planned originally.

Meanwhile, the local governments echoed the central government stimulus program actively, which accounted for 70 to $75 \%$ of budgetary expenditure on fixed investments. In particular, up to the end of 2008, among 31 administrative regions in China, 24 administrative regions announced investment plans. For example, Yunnan and Liaoning provinces announced 3 trillion and 1.3 trillion RMB investment plans, respectively. Table 1 summarises the economic stimulus plans announced by 24 local governments immediately following the economic stimulus package announced by the central government.

Table 1. Economic stimulus plans announced by local governments

\begin{tabular}{llll}
\hline Provinces & Announced plan & Provinces & Announced plan \\
\hline Anhui & 389 & Jiangsu & 950 \\
Beijing & 150 & Jilin & 400 \\
Chongqing & 1300 & Liaoning & 1300 \\
Fujian & 216.7 & Neimenggu & 160 \\
Guangdong & 2300 & Shandong & 800 \\
Guangxi & 200 & Shanghai & 500 \\
\hline
\end{tabular}




\begin{tabular}{llll}
\hline Guizhou & 3000 & Shaanxi & 206 \\
Hainan & 207 & Shanxi & 1000 \\
Hebei & 588.9 & Sichuan & 3000 \\
Henan & 1200 & Tianjin & 1500 \\
Hubei & 7000 & Yunnan & 3000 \\
Hunan & 829.2 & Zhejiang & 350 \\
\hline
\end{tabular}

Source: http://www.china.com.cn/economic/txt/2008-11/24/content 16813059.htm, accessed $24^{\text {th }}$ November 2008. All numbers are in billions RMB.

Table 2 lists detailed information of the investment capital distribution. In Panel A, we summarise the distribution of the investment capital across priority areas intended by the central government for both the initial plan and the revised plan. According to the initial plan that was announced by the head of the National Development and Reform Commission (NDRC) in late 2008, 45\% of total investment would be awarded to transport and power infrastructure and $9.25 \%$ to rural village infrastructure. Later on, in early 2009, the NDRC revised the economic stimulus plan by reducing the investment in transport and power infrastructure and environmental investment from $45 \%$ to $37.5 \%$ and $8.75 \%$ to $5.25 \%$, respectively. The proportion of investments in five other areas has been increased slightly (see figures in Table 2). In Panel B, we re-summarize the investment capital distribution across the industries classified by the China Securities Regulatory Commission (CSRC). We find that new investment has been highly concentrated in more favoured industries (i.e., priority-areas) including construction, technology and culture while less favoured industries get very little.

Table 2. Economic stimulus capital disbursement by industries

\begin{tabular}{lllll}
\hline & Initial plan & & Revised plan & \\
\cline { 2 - 4 } & Disbursement & Percentage & Disbursement & Percentage \\
\hline Panel A: Investment distribution by & priority-areas announced by NDRC & & $37.5 \%$ \\
\hline Transport and Power infrastructure & 1800 & $45 \%$ & 1500 & \\
(railroad, road, airport, electricity & & & & \\
grid) & & & 370 & $9.25 \%$ \\
Rural village infrastructure & 370 & $9.25 \%$ & 210 & $5.25 \%$ \\
Environmental investment & 350 & $8.75 \%$ & 400 & $9.25 \%$ \\
Affordable housing & 280 & $7 \%$ & 370 & $3.75 \%$ \\
Technological innovation & 160 & $4 \%$ & & $25 \%$ \\
and structural adjustment & & & 150 & $100 \%$ \\
Health and education & 40 & $1 \%$ & 1000 & 0 \\
Post-earthquake construction & 1000 & $25 \%$ & 4000 & $81.75 \%$ \\
Total & 4000 & $100 \%$ & 0 \\
\hline Panel B: Investment distribution by & industry classification according to CSRC & 0 \\
\hline Agriculture & 0 & 0 & 0 & 0 \\
Construction & 3450 & $86.25 \%$ & 3270 & 0 \\
Mining & 0 & 0 & 0 & 0 \\
Manufacture & 0 & 0 & 0 & $9.25 \%$ \\
Public utility & 0 & 0 & 0 & 0 \\
Retailing & 0 & 0 & 0 & 0 \\
Transportation & 0 & 0 & 370 & 0 \\
Technology & 160 & $4 \%$ & 0 & \\
Finance & 0 & 0 & & \\
\hline
\end{tabular}




\begin{tabular}{lllll}
\hline Real estate & 0 & 0 & 0 & 0 \\
Public service & 0 & 0 & 0 & 0 \\
Culture & 40 & $1 \%$ & 150 & $3.75 \%$ \\
Conglomerate & 350 & $8.75 \%$ & 210 & $5.25 \%$ \\
Total & 4000 & $100 \%$ & 4000 & $100 \%$ \\
\hline
\end{tabular}

Source: Website of the National Development and Reform Commission (NDRC), China, Changyong Wang (2009). "Facelift for China's Economic Stimulus Plan", 6 ${ }^{\text {th }}$ March.

http://english.caijing.com.cn/2009-03-06/110114405.html. All numbers are in billions RMB.

\subsection{Bank loan supply in China}

Though more favoured industries received most government investment as a result of the stimulus package (see figures in Table 2), bank borrowing and firm investments in less favoured industries were also influenced by the stimulus package due to the increase of bank loan supply following the stimulus package. Bank loan supply in China has increased sharply since the stimulus package was announced for the following reasons: (1) the central government loosened monetary policy by reducing the benchmark deposit interest rate and the bank reserve requirements on deposits (the benchmark deposit interest rate and the bank reserve requirements on deposits were adjusted four times in the second half of 2008, decreasing from $3.87 \%$ to $2.25 \%$, and from $17.5 \%$ to $15.5 \%$ respectively; They were kept at this very low level until the fourth quarter of 2010), both measures increase the money supply in hands of banks; and (2) the announcement of the stimulus package sent a very powerful signal from the central government to the government-controlled bank system that banks should try their best to guarantee the growth of the whole economy. And thus Chinese banks, especially the big five banks, which account for more than $75 \%$ of market share in terms of total deposits in 2008, responded actively by outlining specific policies to support loan applications, especially applications from the areas emphasised by the central government ${ }^{3}$. Joint-equity banks also announced similar policies to loosen bank loan requirements shortly thereafter in the fourth quarter of 2008, causing the new bank credit to grow by 4.2 trillion RMB in 2008, and more than double to 9.6 trillion RMB in 2009, and 8 trillion in 2010. Figure 1 shows that money supply (M2) and bank loan supply have increased significantly since the fourth quarter of 2008, and this expansionary trend lasts to the fourth quarter of 2013 (the end of our empirical sample). Figure 2 shows that firms' average bank loan level suddenly increased from the fourth quarter of 2008. Though it has been reduced slightly since 2011, the average level was still higher than that before the announcement of the economic stimulus package. This huge increase of bank loan supply has been claimed to have caused a

\footnotetext{
${ }^{3}$ Although, according to the Commercial Bank Law, the ratio of loans to deposits should be less than $75 \%$ for commercial banks, there were still a large gap of 3.7 trillion for the big five banks to reach the $75 \%$ cap (calculation based on the data at the end of November 2008), and governors of the big five banks were all confident that they would satisfy government requirements about capital infusion.
} 
number of problems to the whole economy, such as leading to a crowding-out effect over investment by non-state-owned firms, due to the fact that most of the increased bank loan supply is allocated to state-owned sectors/firms. However, there is still no empirical evidence about this type of question. Therefore, this study examines how the increased bank loan supply shock has influenced bank lending decisions, how the increased bank loan supply is allocated between SOEs and non-SOEs, and whether firms (SOEs/non-SOEs) managed to invest the increased funds based on their investment opportunities.

Figure 1. Quarterly data on money supply and bank loan supply (Unit: 100 million RMB)

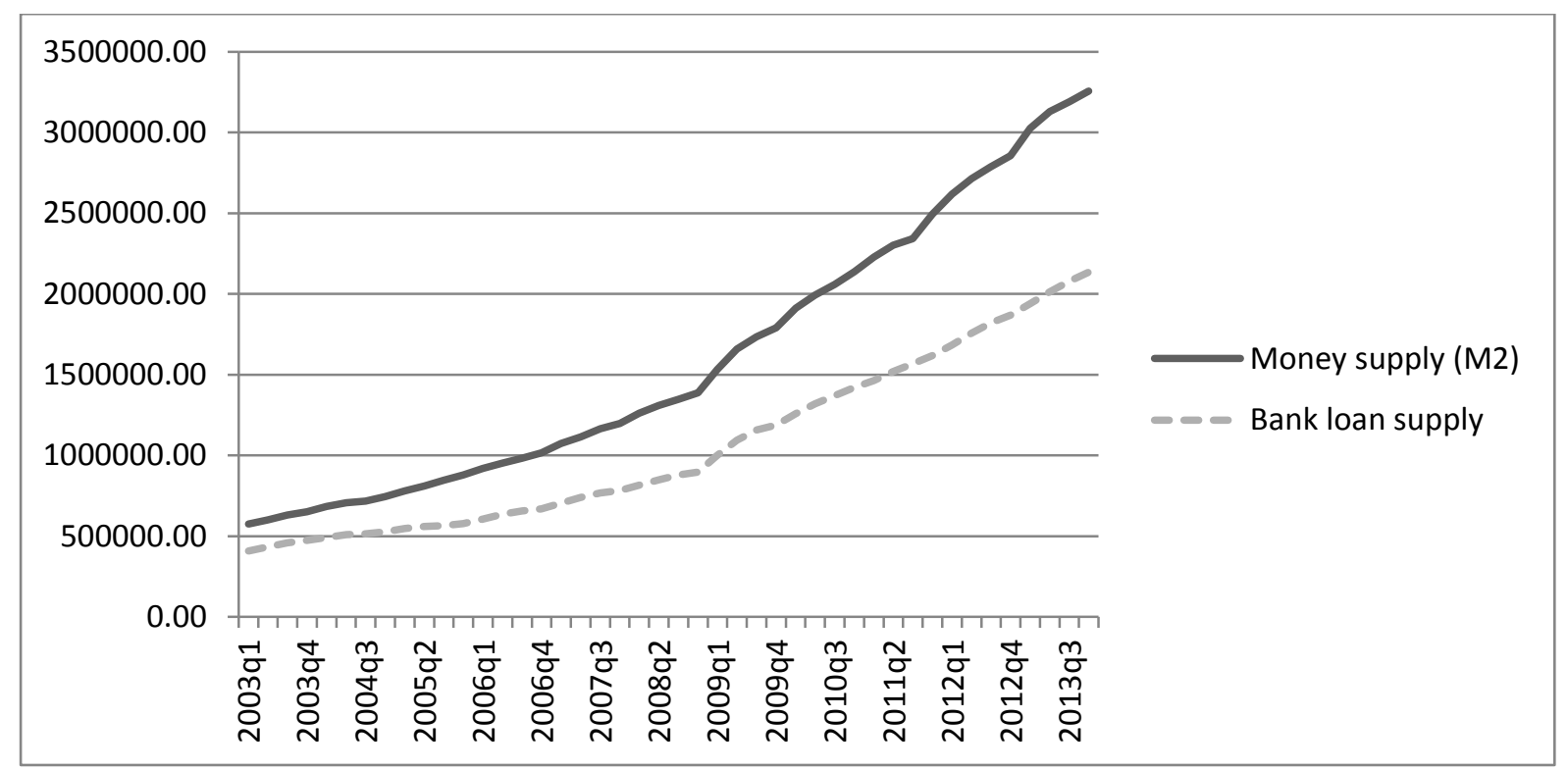

This figure depicts the trends of quarterly money supply and bank loan supply over our sample period. Data sources: collected and calculated from the website of The People's Bank of China at: http://www.pbc.gov.cn/diaochatongjisi/116219/116319/116351/index.html.

Figure 2. The change of firm bank loan level

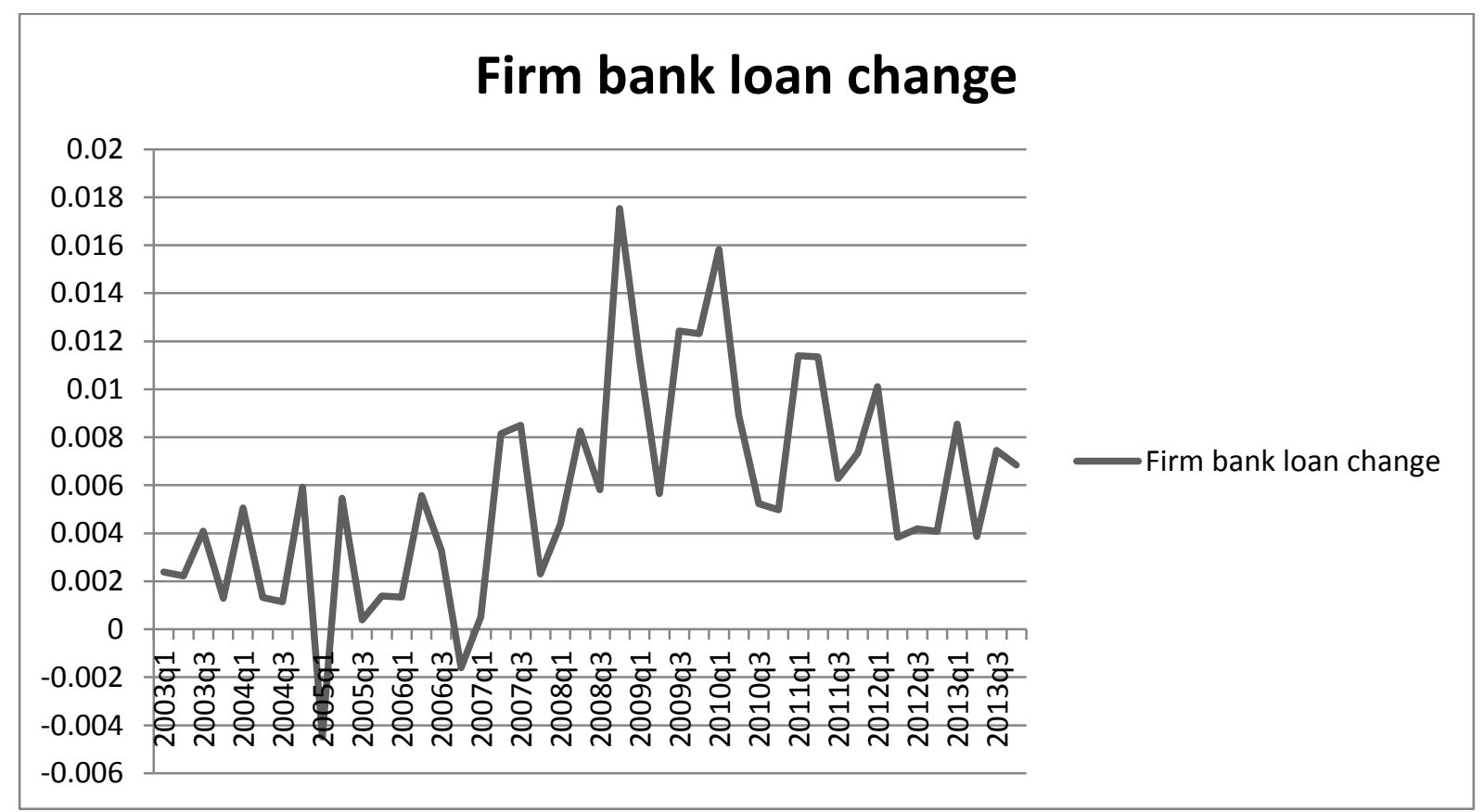


This figure depicts the quarterly change of firm bank loan level of all sample firms in this study. Data sources: collected and calculated from the CSMAR database.

\subsection{Hypothesis development}

\subsubsection{Economic stimulus package and bank loans}

Our first hypothesis relates to the effect of the bank loan supply shock on firms' debt financing decisions. Based on the implicit assumption that external capital is infinitely elastic, a firm's financing decision is solely determined by a firm's demand for debt (Modigliani and Miller, 1958). However, with the presence of capital market frictions, recent evidence argues that the availability of external finance is a key determinant of a firm's debt financing decision (Titman, 2002; Faulkender and Petersen, 2006; Leary, 2009).

In the Chinese capital market, bank loans are the main source of external finance for corporations, due to the underdeveloped stock and bond market (Cull and $\mathrm{Xu}, 2000$; Firth et al., 2008). In this sense, firms in China are mostly bank-dependent and the borrowings of most firms are supported by bank loans (Firth et al., 2012). Therefore, we expect that the bank borrowing of Chinese firms is very sensitive to increased government direct lending through the state-owned banking system, following the implementation of the economic stimulus package. Economic theories provide two views of how government direct lending influences the general economy: the Keynesian view and the neoclassical view. Thus we attempt to answer the question of how government direct lending influences corporate financing policies based on these two views.

The Keynesian view suggests that the economic stimulus packages through government direct lending are helpful to the whole economy after the financial tsunami. This is because commercial banks tend to keep too much precautionary liquidity during the crisis period and are thus reluctant to lend, which causes market failure. By imposing government direct lending, the government cures the market failure by providing additional liquidity to the market and encourages banks to lend (Giannetti and Simonov, 2009; Tong and Wei, 2012; Chen et al., 2014; Lin et al., 2014).

Following our descriptions in Section 2.2, bank loan supply has grown at an explosive pace since the announcement of the stimulus package by the central government, due to explicit policies designed to ease provision of credit, which sends a very powerful signal to banks that they are expected to rapidly ramp up their lending. Therefore, we expect that the bank loans to Chinese firms (both SOEs and non-SOEs) should increase significantly after 
the implementation of the economic stimulus package and develop our first hypothesis as follows:

Hla: The economic stimulus package led to more bank loan access for both SOEs and non-SOEs.

Although the increase in government direct lending may stimulate the economy to recover from the financial tsunami, the neoclassical view, however, suggests that such direct government lending may cause long-term inefficiency in the economy because of the incomplete use of government resources, the so-called 'Keynesian inefficiency'. One type of inefficiency caused by increased government direct lending in the Chinese market may be that the increased resources are primarily allocated to SOEs because the state-owned banks are inclined to lend to SOEs, following the objectives set by politicians and bureaucrats, to serve both political and economic goals (Cull and Xu, 2003; Naughton, 2009). Thus, SOEs' financing policy should be more sensitive to the exogenous shock of bank loan supply, and we argue that SOEs are more likely to receive more bank loans regardless of their performance and creditworthiness after the introduction of the economic stimulus package.

However, non-SOEs may be treated differently. As non-SOEs have a short banking relationship and face severe information asymmetry with state-owned banks, they are discriminated against in getting bank loans. Existing evidence also suggests that the private sector survives mainly due to informal financing based on relationships (Allen et al., 2005; Chen et al., 2013), and banks use commercial judgements when deciding to extend credit to non-SOEs (Firth et al., 2009). The literature has shown that since the implementation of the economic stimulus package, most of the funds have been injected into SOEs for investment and the private sector has contracted (Wong, 2011). Therefore we develop our second hypothesis as follows:

H1b: After the implementation of the stimulus package, bank loans to SOEs increased much more than bank loans to non-SOEs.

We further expect that the incentive of banks, especially those state-owned banks, to lend primarily to SOEs may be enhanced during the financial crisis, when the credit risk is high, because they believe the government will provide an implicit guarantee for the debts of SOEs, and this implicit guarantee helps to mitigate the credit risk faced by banks. Therefore, banks lend the increased capital supply to SOEs without too much consideration about their profitability after the implementation of the economic stimulus package, and thus we have the following hypothesis. 
H1c: After the implementation of the stimulus package, bank loans to SOEs became less responsive to firm profitability.

\subsubsection{The economic stimulus package and corporate investment}

As discussed above, following the Keynesian economic theory, Chinese firms may be reluctant to make investments after the financial tsunami because they have strong incentives to hold cash to avoid the liquidity problem. However, the economic stimulus package and the associated increased government direct lending may cure the inverse effect of the financial crisis on corporate investment by enabling firms to obtain more bank loans. Based on this view, we expect that Chinese firms will increase their investment following the implementation of the stimulus package.

However, compared to non-SOEs, investment made by SOEs may increase more following the stimulus package due to the fact that SOEs have better access to financial resources through increased bank loan supply. Thus we develop the following hypothesis:

H2a: The economic stimulus package boosted investments by both SOEs and non-SOEs. However, after the implementation of the stimulus package, investments by SOEs increased much more than investments by non-SOEs.

Given the fact that SOEs receive more bank loans following the implementation of the economic stimulus package, another related question is whether such a stimulus package influences firm investment decisions. The aim of the economic stimulus package is to help the whole economy to recover through boosting corporate investment, so that both central and local governments spare no effort in urging that bank loans should flow through to the firm level. For example, the governor of Guangxi province announced that he would encourage banks to speed up bank loan disbursement (Guangxi Daily, 2009). As a consequence, bank loans derived from the stimulus package are considered as 'free' resources for firms rather than financial obligations, and this relatively easy access to bank loans encourages firms to engage in suboptimal investments and invest more, no matter whether their investment opportunities are promising or not. Thus, we conjecture that firm investment expenditure will be less responsive to its investment opportunities after the implementation of the stimulus package. Furthermore, relative to non-SOEs, SOEs receive most of the 'free' resources and they are more likely to be influenced by government intervention to make investments for government objectives (to push the growth rate of the economy) rather than financial objectives, and are thus more likely to be involved in investments that are less responsive to investment opportunities. Therefore, we form our hypothesis as follows: 
H2b: After the implementation of the stimulus package, SOEs investments became less responsive to investment opportunities.

\subsubsection{The effect of the economic stimulus package on bank lending and firm investment decisions across industries and regions}

We next examine whether the influence of the economic stimulus package on bank lending and firm investment decisions differs across industries and regions. As we describe in Section 2.1 above, there are large variations in capital injection across industries and regions. The composition of investments had been directed toward specific industries that would boost consumption or have a direct impact on people's livelihood. As a consequence of government directions, bank loans and firm investments were mainly focused on industries such as transport and power infrastructure (railways, roads, airports and the electricity grid), rural village infrastructure, environment investment, affordable housing, technological innovation and health and education. Thus, firms from these industries are more likely to receive government-supported bank loans and in turn involve more investment activities. Moreover, due to the high degree of politicisation and strong encouragement of bank lending, firms from these government-favoured industries will receive more bank loans regardless of their profitability. These firms would also invest more without considering investment potential of proposed projects (Naughton, 2009).

In addition, along with the announcement of the economic stimulus package by the central government on the $5^{\text {th }}$ November 2008, many local governments also announced their own economic stimulus plans to be implemented at the provincial level. In this sense, bank loan supply shocks may vary across provinces as unequal amounts of bank loans would be injected by each local government. As outlined above, firms from provinces with larger bank loans injected will receive more bank loans and invest more. We expect industry and region should have a stronger influence on bank lending and firm investment decisions for nonSOEs because the government policy may help non-SOEs to overcome institutional barriers. Therefore, we formulate the following hypothesis:

H3: The influence of the economic stimulus package on bank lending and firm investment decisions was more significant for firms from industries and regions with more government-injected capital, especially in non-SOEs.

\subsubsection{The effect of the economic stimulus package on bank lending and firm investment decisions in firms with and without political connections}

The above hypotheses have considered the supply side effect on firms' debt financing, namely the change in bank loan supply, and how this response varies across industries and 
regions. However, the variations in firms' debt financing and investment decisions are also driven by the firms' demand side forces, and existing literature documents that many of the proposed proxies of firm characteristics are correlated with firms' financial structure and investment expenditure decisions. Thus, in this section, we try to explore how firms' demand side force interacts with the supply side force. In particular, we focus on firms' political connections from the demand side perspective. Specifically, an SOE is defined as politically connected if any CEO or chairman is a current or former officer in the government or the military (Fan et al., 2007); a non-SOE is defined as politically connected if the CEO, chairman or largest shareholder is a current or former officer in the government or the military. In our sample, about $27 \%$ of SOEs are politically connected and $36 \%$ of non-SOEs.

Evidence from emerging markets suggests that firms have a strong incentive to establish political connections to seek rents from the government, in the form of more access to bank loans (Claessens et al., 2008; Faccio, 2010). In this sense, political connections are a good reflection of a firm's demand for bank loans, all else being equal. Thus, we expect that firms with political connections are likely to receive more bank loans. However, we are more concerned about the different effects of political connections between SOEs and non-SOEs. For SOEs, their banking relationships have already been established because both banks and firms are owned by the government and SOEs are preferred by state-owned banks in terms of extending credits (Cull and $\mathrm{Xu}, 2000$ ). In this case, political connections do not provide additional benefits for accessing more bank loans. Therefore, the effect of political connections in SOEs may be diluted by state ownership (Wu et al., 2012). For non-SOEs, the situation could be different. Due to the weaker bank-firm relationship and more severe information asymmetry, banks face a higher ex ante cost of collecting non-SOE information and ex post cost of monitoring, and are less likely to extend credit to the private sector (Firth et al., 2009). Thus, political connections can help non-SOEs to overcome institutional barriers to obtain more bank loans (Wu et al., 2012). We thus expect that political connections should have a stronger influence on bank lending and firm investment decisions for non-SOEs because political connections in non-SOEs can enhance their ability to obtain bank loans which can be used for investment. Therefore, we formulate the following hypothesis:

H4: The influence of the economic stimulus package on bank lending and firm investment decisions was stronger for non-SOEs with political connections than those without.

\section{Sample and methodology}

\subsection{Sample selection}


In this study, quarterly data is applied and firm-level information is obtained from the Chinese Stock and Market Accounting Research (CSMAR). Our sample starts with all listed firms on both Shanghai and Shenzhen stock exchanges from the first quarter of 2003 to the fourth quarter of $2013^{4}$. Initially, we collected a total population of 64,116 firm-quarter observations. Following common practice, we deleted 1,311 firm-quarter observations from the financial industry and 2,256 firm-quarter observations flagged with ST or ST*. We also excluded 4,342 firm-quarter observations with missing information on the variables that are used in this study. All the continuous variables are winsorized at the $1 \%$ level to eliminate the outlier effects. Our final sample consists of 1,526 firms and 56,207 firm-quarter observations.

\subsection{Methodology}

Since the economic stimulus package constitutes a nation-wide exogenous shock, we establish an equation to explain the determinants of bank loan changes in the spirit of Bertrand et al. (2007). This method allows us to explore the dynamic change in firm financing policy following the implementation of the stimulus package which is our focus. We therefore include a dummy variable Stimulus in our model. We also include a dummy variable SOEs to gain an understanding of the potential difference in bank lending incentives between SOEs and non-SOEs, and develop the following equation:

$$
\begin{aligned}
{\Delta \text { BankLoan }_{i t}=}_{\text {S }} & \alpha_{0}+\alpha_{1} \text { Stimulus }_{i t}+\alpha_{2} \text { Stimulus }_{i t} * \text { SOEs }_{i t}+\alpha_{3} \text { SOEs }_{i t} \\
& +\alpha_{4} \text { ROS }_{i t-1}+\alpha_{5} Q_{i t-1}+\alpha_{6} \text { Size }_{i t}+\alpha_{7} \text { Tangibility }_{i t} \\
& +\alpha_{8} \text { Political }_{i t}+\alpha_{9} \text { Board }_{i t}+\alpha_{10} \text { Indep }_{i t}+\varepsilon_{i t}
\end{aligned}
$$

where $\Delta$ BankLoan is the change in bank loans (i.e. net newly granted bank loans) in the current quarter. In the empirical analysis, we look into changes in both total bank loans and long-term bank loans. Stimulus is a dummy variable equal to 1 for firm-quarter observations falling in the post-stimulus period and 0 otherwise. SOEs is a dummy variable equal to 1 for SOEs and 0 for non-SOEs. We test H1a by examining Stimulus and expect the coefficient of this variable to be significantly positive, and test H1b by examining Stimulus*SOEs and expect the coefficient of this interaction term to be significantly positive.

Consistent with the literature (Firth et al., 2009; Zheng and Zhu, 2013), we also include several control variables in equation (1). ROS is return on sales, which is the proxy for firm profitability. Better performing firms are likely to obtain more bank loans, so the coefficient is expected to be positive. $Q$ is the value of Tobin's Q calculated as the ratio of firm market value to replacement value, which is used as a proxy for firm investment opportunity (Firth et

\footnotetext{
${ }^{4}$ We start our sample in 2003 because new accounting and auditing standards were applied in 2002.
} 
al., 2008; Chen et al., 2011). As firms with better investment opportunities are likely to receive more bank loans, we expect a positive coefficient for $Q$. Size is the natural log of firm total assets. Since firms with more collateral assets face less difficulty in getting bank loans, we include Tangibility, defined as the ratio of tangible assets to firm total assets, to control for collateral information, and we expect a positive coefficient. Political connections are helpful in accessing bank loans, so we include Political, defined as a dummy variable equal to 1 if the firm is politically connected, and the coefficient is expected to be positive. We also include some proxies for corporate governance, which influences bank lending decisions. These are Board, measured as the log of the total number of directors on the boards, and Indep, measured as the ratio of independent directors to the total number of directors on the boards. We also include quarter, industry and province fixed effects. Following previous studies, we use the one-quarter lag of firm performance and Tobin's Q in the regression.

We further examine whether the stimulus package has an impact on bank lending decisions for SOEs and non-SOEs, by estimating the following equation for both the SOE and non-SOE subsamples, respectively. In accordance with the argument in the literature that an optimal lending decision is made if a newly granted bank loan is dependent on a firm's profitability (Zheng and Zhu, 2013), we use the sensitivity of newly granted bank loans to a firm's profitability as the proxy for the bank's lending decision, where strongly positive sensitivity indicates an optimal lending decision. The equation is expressed as follows:

$$
\begin{aligned}
\Delta \text { BankLoan }_{i t}= & \alpha_{0}+\alpha_{1} \text { Stimulus }_{i t}+\alpha_{2} \text { Stimulus }_{i t} * \operatorname{ROS}_{i t-1}+\alpha_{3} \text { ROS }_{i t-1}+\alpha_{4} Q_{i t-1} \\
& +\alpha_{5} \text { Size }_{i t}+\alpha_{6} \text { Tangibility }_{i t}+\alpha_{7} \text { Political }_{i t}+\alpha_{8} \text { Board }_{i t} \\
& +\alpha_{9} \text { Indep }_{i t}+\varepsilon_{i t}
\end{aligned}
$$

In contrast to equation (1), we include one interaction term between Stimulus and ROS to test H1c, that is, whether a bank's lending decision is affected by the implementation of the stimulus package. All the other variables are defined in Table 3.

Regarding firms' investment decisions, we follow the argument of Bushman et al. (2011) to relate firm investment growth to changes in investment opportunities (marginal Q). This method has also been applied by other studies (Zheng and Zhu, 2013), and is expressed as follows:

$$
\begin{aligned}
\operatorname{Ln}\left(I_{i t} / I_{i t-1}\right)= & \alpha_{0}+\alpha_{1} \text { Stimulus }_{i t}+\alpha_{2} \text { Stimulus }_{i t} * \text { RET }_{i t-1}+\alpha_{3} \text { RET }_{i t-1} \\
& +\alpha_{4} \text { Leverage }_{i t-1}+\alpha_{5} \text { Income }_{i t}+\alpha_{6} \text { Size }_{i t}+\alpha_{7} \text { Sale }_{i t-1} \\
& +\alpha_{8} \text { Tangibility }_{i t}+\varepsilon_{i t}
\end{aligned}
$$


where $\operatorname{Ln}\left(I_{i t} / I_{i t-1}\right)$ is the log of the change in a firm's investment expenditures in the current quarter, the proxy for investment growth. We follow Chen et al. (2011) to measure investment expenditure as the ratio of capital expenditure (cash payments for fixed assets, intangible assets, and other long-term assets less cash receipts from selling these assets) to total assets in the current quarter. Prior studies also applied other proxies for investment, which we consider for the robustness tests ${ }^{5}$. RET measures the change in investment opportunities (marginal Q), which equals the log of 1 plus lagged industry stock returns. In particular, the industry stock returns are measured as the average holding period stock return for all sample firms in a specific industry. We estimate equation (3) for the SOE and nonSOE subsamples. We test H2a by examining Stimulus and expect the coefficient of this variable to be significantly positive, and test $\mathrm{H} 2 \mathrm{~b}$ by examining Stimulus $*$ RET and expect the coefficient to be significantly negative only for SOE subsample.

Following prior studies (Firth et al., 2008; Chen et al., 2011), we include the following control variables. Leverage is defined as the proportion of total debt to total assets. Highly leveraged firms pay more interest and have fewer resources for investments, thus we expect a negative coefficient for this variable. Income is used to measure internal funds available for investments, which is measured as the ratio of net income plus depreciation to total assets. Sale is the net sales scaled by total assets. As larger internal funds provide a firm with more financial resources for investments, we expect positive coefficients for both Income and Sale. We also include quarter, industry and province fixed effects." All other variables are defined as in Table 3. To remain consistent with the existing literature, we use the one-quarter lag of leverage and sales level in the regression. Table 3 summarises the definitions of all variables used in this study for both univariate and multivariate analysis.

Table 3. Variables and definitions

\begin{tabular}{ll}
\hline Variable & Definitions \\
\hline Stimulus & Equals 1 for firm-quarter observations falling in the post-stimulus period, and 0 for \\
& the pre-stimulus period. In particular, pre-stimulus period covers 2003 to the third \\
& quarter of 2008, and post-stimulus period covers the fourth quarter of 2008 to 2013. \\
$\Delta$ Totalloan & The change in total bank loans in current quarter \\
$\Delta$ Longloan & The change in long-term bank loans in current quarter \\
Investment $(\mathrm{I})$ & Capital expenditure/Total assets in the current quarter \\
$\mathrm{Ln}\left(\mathrm{I}_{\mathrm{it}} / \mathrm{I}_{\mathrm{it}-1}\right)$ & The growth of investment expenditure in current quarter \\
$\mathrm{RET}$ & Natural log of 1 plus industry stock return in the current quarter \\
$\mathrm{ROS}$ & Net income/Sales in the current quarter \\
Leverage & Total debt/Total assets in the current quarter \\
Income & (Net income + depreciation)/Total assets in the current quarter \\
$\mathrm{Q}$ & Market value/Replacement value in the current quarter \\
Size & Natural log of total assets in the current quarter \\
\hline
\end{tabular}

\footnotetext{
${ }^{5}$ These measures include (1) the ratio of change in net fixed assets plus depreciation to total net fixed assets (Pindado et al., 2011; Firth et al., 2012) and (2) net capital expenditure to total assets (Firth et al., 2008).
} 


\begin{tabular}{|c|c|}
\hline Sale & Sales/Total assets in the current quarter \\
\hline Tangibility & Tangible assets/Total assets in the current quarter \\
\hline Board & Number of total directors on the boards in the current quarter \\
\hline Indep & $\begin{array}{l}\text { Number of independent directors/Total number of directors on board in the current } \\
\text { quarter }\end{array}$ \\
\hline $\begin{array}{l}\text { Political } \\
\text { SOEs }\end{array}$ & $\begin{array}{l}\text { Dummy equals } 1 \text { for firms with politically connected executives or large } \\
\text { shareholders } \\
\text { Dummy equals } 1 \text { for state-owned enterprises and } 0 \text { for non-state-owned enterprises }\end{array}$ \\
\hline
\end{tabular}

\section{Empirical results}

\subsection{Summary statistics and univariate test}

Table 4 presents the summary statistics of all variables in this study. From the table, we observe that the average change in total bank loan ratio is $0.66 \%$, indicating that the bank loan ratio increased quarterly. We also observe that the mean of investment growth is 0.02 and the quarterly investment expenditure is $1.48 \%$ of total assets. Moreover, the change in investment opportunity is 0.03 . The average Tobin's $\mathrm{Q}$ is 1.70 and the median value is 1.32 , and the average internal funds and sales level are $7.78 \%$ and $17.91 \%$ of total assets respectively, which are similar to the results by Chen et al. (2011).

Table 4. Summary statistics of all variables

\begin{tabular}{|c|c|c|c|c|c|}
\hline & Mean & Median & $25^{\text {th }}$ quartile & $75^{\text {th }}$ quartile & StD \\
\hline$\Delta$ Totalloan $(\%)$ & 0.66 & 0.02 & -1.08 & 2.16 & 4.98 \\
\hline$\Delta$ Longloan $(\%)$ & 0.25 & 0 & -0.01 & 2.36 & 5.53 \\
\hline $\operatorname{Ln}\left(\mathrm{I}_{\mathrm{it}} / \mathrm{I}_{\mathrm{it}-1}\right)$ & 0.02 & 0.01 & -0.66 & 0.65 & 1.16 \\
\hline Totalloan (\%) & 23.96 & 23.01 & 9.97 & 35.24 & 20.59 \\
\hline Longloan (\%) & 6.56 & 2.11 & 0 & 9.60 & 8.32 \\
\hline Investment (\%) & 1.48 & 0.75 & 0.15 & 2.04 & 2.35 \\
\hline RET & 0.03 & 0.01 & -0.02 & 0.05 & 0.26 \\
\hline $\operatorname{ROS}(\%)$ & 3.91 & 4.53 & 0.96 & 10.92 & 16.59 \\
\hline Leverage $(\%)$ & 52.35 & 51.91 & 37.24 & 65.45 & 0.23 \\
\hline Income $(\%)$ & 7.78 & 3.71 & 0.13 & 16.09 & 2.20 \\
\hline Tobin's Q & 1.70 & 1.32 & 1.06 & 1.86 & 1.11 \\
\hline Size (million) & 6,520 & 2,190 & 1,040 & 5,080 & 4,970 \\
\hline Sale $(\%)$ & 17.91 & 14.56 & 8.38 & 23.09 & 14.07 \\
\hline Tangibility (\%) & 27.39 & 24.32 & 13.27 & 39.28 & 5.71 \\
\hline Board & 9.30 & 9 & 9 & 10 & 2.00 \\
\hline Indep (\%) & 35.79 & 33.33 & 33.33 & 37.50 & 5.51 \\
\hline Political & 0.31 & 0 & 0 & 1 & 0.46 \\
\hline
\end{tabular}

Table 5 presents the results of univariate tests, by comparing the change in bank loans and corporate investment growth before and after the introduction of the economic stimulus package, for the full sample, SOE and non-SOE subsamples. In Panel A, we compare the change in bank loans. In the first column for the full sample, we find that the average bank loan change is higher after the introduction of the economic stimulus package, and the difference is statistically significant (t-value is -2.10). When we split our total sample into both SOEs and non-SOEs in columns 2 and 3, we find that this significant difference holds for SOEs while the difference in non-SOEs is insignificant. In Panel B, we compare the 
growth rate of corporate investment, and we find that the investment growth is significantly higher for the post-stimulus period, and this difference is also significant for SOEs while insignificant for non-SOEs. These univariate tests lend primary support to our hypothesis that compared to non-SOEs, SOEs are able to increase their bank loans and investment significantly following the bank loan supply shock after the implementation of the stimulus package. In the last column in Table 5, we further report the difference-in-difference tests of change in bank loans and investment of SOEs and non-SOEs, and before and after the introduction of the stimulus package. The statistically and economically significant difference-in-difference results confirm that after the introduction of the economic stimulus package, both the increase in total bank loans and investment growth are significantly higher for SOEs than non-SOEs.

Table 5. Univariate tests before and after the introduction of the economic stimulus package

\begin{tabular}{|c|c|c|c|c|}
\hline & Full sample & SOEs & Non-SOEs & $\begin{array}{l}\text { Difference (t-value) } \\
\text { SOE vs. non-SOE }\end{array}$ \\
\hline \multicolumn{5}{|c|}{ Panel A: Change in total bank loan ratio } \\
\hline Before & $0.59 \%$ & $0.62 \%$ & $0.50 \%$ & $0.12 \% *(1.81)$ \\
\hline After & $0.73 \%$ & $0.82 \%$ & $0.58 \%$ & $0.24 \% * *(2.52)$ \\
\hline Difference (t-value) & $-0.14 \% * *(-2.10)$ & $-0.20 \% * *(-2.46)$ & $-0.08 \%(-1.10)$ & $-0.12 \% * *(-2.36)$ \\
\hline \multicolumn{5}{|l|}{ Before vs. After } \\
\hline \multicolumn{5}{|c|}{ Panel B: Corporate investment growth } \\
\hline Before & 0.012 & 0.014 & 0.011 & $0.003(0.86)$ \\
\hline After & 0.025 & 0.038 & 0.018 & $0.020 * * *(3.11)$ \\
\hline Difference (t-value) & $-0.013 * *(-2.08)$ & $-0.024 * * *(-2.43)$ & $-0.007(-1.19)$ & $-0.017 * *(-2.23)$ \\
\hline
\end{tabular}

$*, * *$, and $* * *$ indicate the significance levels at the $10 \%, 5 \%$, and $1 \%$, respectively.

\subsection{Economic stimulus package, bank lending and firm investment decisions}

\subsubsection{Economic stimulus package and change in bank loans at firm level}

In this section, we conduct multivariate analysis in order to provide empirical evidence regarding how the increase of monetary supply impacts the change in bank loans using the regression model of equation (1). The results are reported in Table 6. In first two columns, we apply the change in total bank loans as the dependent variable. We observe from column 1 that the estimated coefficient on Stimulus is positive and significant at the $1 \%$ level (t-value is 5.19), indicating that after the introduction of the economic stimulus package the average quarterly increase of total bank loans is higher than that before the stimulus package. The results in column 2 show that the coefficient of interaction term Stimulus*SOEs is also positive and statistically significant, indicating that positive relationship between the monetary supply shock and change of total bank loans is much stronger in SOEs compared to non-SOEs. We also observe the coefficients of $R O S$ are positively and significantly related to the quarterly change of total bank loans. For example, in column 1, the coefficient of ROS is 
0.013. Table 4 shows that the standard deviation for $R O S$ is 0.1659 . Hence, a one-standarddeviation increase in $R O S$ yields a $0.22 \%$ increase in total bank loan change. As the mean value for total bank loan change is $0.66 \%$, so a one-standard-deviation increase in $R O S$ creates $33.3 \%$ increase in total bank loan change. In columns 3 and 4, we use the change in long-term bank loans as the dependent variable to provide additional evidence and similar results are found, indicating that firms, especially SOEs, are able to obtain more long-term loans after the introduction of the economic stimulus package. We also find that $R O S$ is also positively and significantly related to the change of long-term loans. The coefficient of $R O S$ is 0.005 , indicating that a one-standard-deviation increase in ROS creates $33.2 \%$ increase in long-term loan change.

Among the control variables, we observe expected signs consistent with previous studies. In particular, firms with political connections are able to obtain more bank loans, though this effect is only significant in the total bank loan regression but insignificant in the long-term loan regression. The result suggests that firms' political connections play a more important role in financing short-term resources than long-term resources. The possible explanation could be that, in our sample, almost $75 \%$ of bank loans are short-term which drives the main results in the total loan regression (Table 4 shows that the proportion of long-term loan ratio to total loan ratio is about 25\%). In addition, Zhu et al. (2010) argue that firms from more favoured industries are likely to obtain long-term loans. As we have already controlled for industry fixed effects, the positive impact of political connections has been diminished. Overall, these results are consistent with our hypotheses $\mathrm{H} 1 \mathrm{a}$ and $\mathrm{H} 1 \mathrm{~b}$ that both SOEs and non-SOEs are able to obtain more bank loans following the stimulus package, and relative to non-SOEs, SOEs' bank loans increase more significantly. These results suggest that the stimulus package and the associated increase of bank loan supply result in a more capital allocation towards SOEs.

Table 6. Effect of the economic stimulus package on the change in bank loans

\begin{tabular}{|c|c|c|c|c|}
\hline \multirow[t]{2}{*}{ Dependent variable: } & \multicolumn{2}{|c|}{ Change in total bank loans } & \multicolumn{2}{|c|}{ Change in long-term bank loans } \\
\hline & 1 & 2 & 3 & 4 \\
\hline Stimulus & $\begin{array}{l}0.015 * * * \\
(5.19)\end{array}$ & $\begin{array}{l}0.013 * * * \\
(5.67)\end{array}$ & $\begin{array}{l}0.006 * * * \\
(3.49)\end{array}$ & $\begin{array}{l}0.005 * * * \\
(3.74)\end{array}$ \\
\hline Stimulus*SOEs & & $\begin{array}{l}0.009 * * \\
(1.98)\end{array}$ & & $\begin{array}{l}0.006 * * * \\
(3.45)\end{array}$ \\
\hline SOEs & & $\begin{array}{l}0.001 * \\
(1.82)\end{array}$ & & $\begin{array}{l}0.002 \\
(0.55)\end{array}$ \\
\hline ROS & $\begin{array}{l}0.013 * * * \\
(2.98)\end{array}$ & $\begin{array}{l}0.013 * * \\
(2.90)\end{array}$ & $\begin{array}{l}0.005 * * \\
(2.43)\end{array}$ & $\begin{array}{l}0.005 * * * \\
(2.40)\end{array}$ \\
\hline Tobin's Q & $\begin{array}{l}0.003 * * * \\
(7.80)\end{array}$ & $\begin{array}{l}0.003 * * * \\
(7.81)\end{array}$ & $\begin{array}{l}0.002 * * * \\
(2.91)\end{array}$ & $\begin{array}{l}0.001 * * * \\
(2.97)\end{array}$ \\
\hline Size & $\begin{array}{l}0.003 * * * \\
(5.25)\end{array}$ & $\begin{array}{l}0.003 * * * \\
(5.18)\end{array}$ & $\begin{array}{l}0.003 * * * \\
(3.65)\end{array}$ & $\begin{array}{l}0.003 * * * \\
(2.89)\end{array}$ \\
\hline
\end{tabular}




\begin{tabular}{lllll}
\hline Tangibility & $0.005^{* * *}$ & $0.005^{* * *}$ & $0.025^{* * *}$ & $0.025^{* * *}$ \\
& $(2.94)$ & $(2.96)$ & $(2.90)$ & $(2.90)$ \\
Political & $0.001^{* *}$ & $0.001^{* *}$ & 0.013 & 0.012 \\
& $(2.12)$ & $(2.17)$ & $(1.51)$ & $(1.45)$ \\
Board & 0.001 & 0.001 & 0.005 & 0.005 \\
& $(0.77)$ & $(0.78)$ & $(0.56)$ & $(0.56)$ \\
Indep & 0.001 & 0.001 & -0.001 & -0.001 \\
& $(1.01)$ & $(1.01)$ & $(-0.33)$ & $(-0.39)$ \\
Constant & $-0.017 * * *$ & $-0.019 * * *$ & $-0.495 * * *$ & $-0.481^{* * *}$ \\
& $(-6.97)$ & $(-6.95)$ & $(-11.06)$ & $(-10.49)$ \\
Industry fixed effect & Included & Included & Included & Included \\
Quarter fixed effect & Included & Included & Included & Included \\
Province fixed effect & Included & Included & Included & Included \\
Adjusted R & 0.27 & 0.28 & 0.31 & 0.32 \\
Observations & 56207 & 56207 & 56207 & 56207 \\
\hline
\end{tabular}

Columns 1 and 2 report the results using the change in total bank loans as the dependent variable. Columns 3 and 4 report the results using the change in long-term bank loans as the dependent variable. Stimulus is a dummy variable, equal to 1 for firm-quarter observations falling in the post-stimulus period and 0 otherwise. SOEs is a dummy variable equal to 1 for SOEs and 0 for non-SOEs. ROS is the return on sales. Tobin's Q is the ratio of firm market value to replacement value. Size is the log of a firm's total assets. Tangibility is the ratio of a firm's tangible assets to total assets. Political is a dummy variable equal to 1 if the firm is politically connected. Board is the log of the number of total directors on the board. Indep is the ratio of independent directors to total directors on the board. The T-statistics are in parentheses and computed using the robust standard error clustered by firm; *,**, and *** indicate the significance levels at the $10 \%, 5 \%$, and $1 \%$, respectively.

\subsubsection{Economic stimulus package and bank lending decisions}

In this section, we examine the effect of the economic stimulus package on bank lending decisions by estimating our equation (2), and report the results in Table 7. Consistent with the results in Table 6, the estimated coefficients on Stimulus are all positive and statistically significant across three specifications. The interaction term Stimulus*ROS is our main concern. In the first column for the full sample, we observe that the estimated coefficient on this interaction term is -0.003 and is significant at the $10 \%$ level (t-value is -1.92), indicating that the connection between change of bank loans and firm profitability becomes weaker after the introduction of the economic stimulus package. This result indicates that a one-standarddeviation increase in ROS creates $37.7 \%$ increase in total bank loan change before the stimulus package, and 30.2\% increase in total bank loan change after the introduction of the stimulus package. In columns 2 and 3, we partition our total sample into SOEs and non-SOEs. In column 2 for the SOEs, we find that the coefficient on Stimulus*ROS is also significantly negative with an even larger magnitude (-0.006 vs. -0.003$)$. This result suggests that banks are less concerned about SOEs' profitability when making lending decisions after the introduction of the stimulus package, which means that the relationship between bank loans and firm profitability becomes weaker for SOEs after the introduction of the stimulus package. However, in column 3 for the non-SOEs, this coefficient becomes insignificant, though negative, indicating that banks' lending decision towards non-SOEs is not affected 
significantly after the introduction of the stimulus package. The Chow test reveals that stimulus package has stronger influence on bank lending decision towards SOEs than nonSOEs $(\mathrm{F}=4.17, \mathrm{p}<0.05)$. Overall, the results in Table 7 support our hypothesis H1c that more bank loans were granted to SOEs regardless of their profitability, while non-SOEs have experienced no significant change. Among the control variables, we observe that political connection is only effective in obtaining more bank loans in non-SOEs, and other control variables show coefficients and signs which are consistent with those in Table 6 .

Table 7. Effect of the economic stimulus package on bank lending decisions

\begin{tabular}{|c|c|c|c|}
\hline \multirow[t]{2}{*}{ Dependent variable: } & \multicolumn{3}{|c|}{ Change in total bank loans } \\
\hline & Full sample & SOEs & Non-SOEs \\
\hline Stimulus & $0.015^{* * *}(5.20)$ & $0.020 * * *(4.82)$ & $0.013 *(1.78)$ \\
\hline Stimulus*ROS & $-0.003 *(-1.92)$ & $-0.006 * *(-2.03)$ & $-0.001(-0.43)$ \\
\hline ROS & $0.015 * * *(8.55)$ & $0.017 * * *(5.62)$ & $0.010 * * *(4.35)$ \\
\hline Tobin's Q & $0.003 * * *(7.80)$ & $0.002 * * *(6.15)$ & $0.004 * * *(4.79)$ \\
\hline Size & $0.009 * * *(8.20)$ & $0.009 * * *(5.88)$ & $0.001 * * *(4.14)$ \\
\hline Tangibility & $0.005 * * *(3.97)$ & $0.003 * * *(3.72)$ & $0.006 * * *(2.99)$ \\
\hline Political & $0.001 * *(2.16)$ & $0.002(0.27)$ & $0.001 * *(2.10)$ \\
\hline Board & $0.001(0.66)$ & $0.003 * *(2.22)$ & $-0.001(-0.94)$ \\
\hline Indep & $-0.002(-1.01)$ & $-0.002(-0.26)$ & $0.003(0.12)$ \\
\hline Constant & $-0.024 * * *(-7.68)$ & $-0.031 * * *(-5.45)$ & $-0.016 * * *(-3.23)$ \\
\hline Industry fixed effect & Included & Included & Included \\
\hline Quarter fixed effect & Included & Included & Included \\
\hline Province fixed effect & Included & Included & Included \\
\hline Adjusted $\mathrm{R}^{2}$ & 0.26 & 0.31 & 0.18 \\
\hline Observations & 56207 & 32450 & 23757 \\
\hline Chow test & & $4.17 * *$ & \\
\hline
\end{tabular}

The dependent variable is the change in the ratio of total bank loans to total assets. Stimulus is a dummy variable, equal to 1 for firm-quarter observations falling in the post-stimulus period and 0 otherwise. ROS is the return on sales. Q is the ratio of firm market value to replacement value. Size is the log of firm total assets. Tangibility is the ratio of a firm's tangible assets to total assets. Political is a dummy variable equal to 1 if the firm is politically connected. Board is the log of number of total directors on the board. Indep is the ratio of independent directors to total directors on the board. The Chow test reports the significance of the difference in the coefficients on the Stimulus*ROS between SOEs and non-SOEs. The T-statistics are in parentheses and computed using the robust standard error clustered by firm; *, **, and *** indicate the significance levels at the $10 \%, 5 \%$, and $1 \%$, respectively.

\subsubsection{Economic stimulus package and firm investment decisions}

In this section, we estimate equation (3) to examine the effect of the economic stimulus package on firm investment decision, measured as the sensitivity of investment growth to the change in investment opportunities. Table 8 below shows the estimation results. Across three specifications, we observe that the estimated coefficients on Stimulus are all positive and statistically significant, and apparently the investment made by SOEs increase more than non-SOEs (coefficients are 0.082 and 0.045 , respectively). This result is consistent with our hypothesis $\mathrm{H} 2 \mathrm{a}$ and confirms the positive role played by the economic stimulus package during the global financial crisis period in encouraging firms to invest, and SOEs increase their investment more significantly than non-SOEs after the introduction of the economic 
stimulus package. We also find that RET has positive and statistically significant coefficients in three specifications, indicating that investment opportunity is an important determinant of firm investment regardless of the firm ownership structure. In column 1, the estimated coefficient of RET suggests that a $10 \%$ increase in investment opportunity results in $0.30 \%$ increase in investment growth before the stimulus package. The interaction term Stimulus*RET is our main concern. In the first column for the full sample, the negative coefficient on Stimulus*RET is what we expect, suggesting that after the introduction of the economic stimulus package, though firms increase their investment expenditure significantly, investment growth becomes less responsive to the change in investment opportunity. In column 2 for the SOEs, we find that the coefficient on Stimulus*RET is negative and significant at the $1 \%$ level ( $\mathrm{t}$-value is -2.63), while in column 3 for the non-SOEs, the coefficient on Stimulus $*$ RET is insignificant. The Chow test reveals that the influence of the stimulus package is significantly different between SOEs and non-SOEs $(\mathrm{F}=7.02, \mathrm{p}<0.01)$. Put together, these results support our main hypothesis $\mathrm{H} 2 \mathrm{~b}$ that firms' investment expenditure has a weaker connection with investment opportunities after the implementation of the stimulus package, which is more pronounced for SOEs than non-SOEs. In addition, the empirical results of weaker association between investment growth and investment opportunities for SOEs since the stimulus package are also consistent with anecdotal observations of overcapacity in some particular industries. For example, at the 2012 China Iron forum, $\mathrm{Mr} \mathrm{Wu}$ Xichun, the President of the China Iron and Steel Industry Association (CISA), claimed that the overproduction in the steel industry was a direct result of the stimulus package, which led to the loss of firms from this industry, including Bao Gang Gu Fen (stock code: 600019$)^{6}$.

Table 8. Effect of the economic stimulus package on firm investment decisions

\begin{tabular}{llll}
\hline Dependent variable & & \multicolumn{2}{c}{ Investment growth } \\
\hline Stimulus & Full sample & SOEs & Non-SOEs \\
Stimulus*RET & $0.062 * * *(5.95)$ & $0.082 * * *(3.30)$ & $0.045^{*}(1.78)$ \\
RET & $-0.027 * *(-2.25)$ & $-0.032 * * *(-2.63)$ & $-0.020(-0.65)$ \\
Leverage & $0.030 * *(4.40)$ & $0.024 * * *(3.06)$ & $0.035^{* * *(3.18)}$ \\
Income & $-0.036(-1.22)$ & $-0.022(-0.93)$ & $-0.098^{*} *(-2.18)$ \\
Size & $0.195(0.77)$ & $0.108(0.59)$ & $0.343(0.68)$ \\
Sale & $0.034 * *(8.14)$ & $0.024 * * *(5.61)$ & $0.050 * *(5.57)$ \\
Tangibility & $0.233 * *(6.19)$ & $0.287 * *(6.07)$ & $0.196 *(2.48)$ \\
Constant & $0.089 * *(4.55)$ & $0.032(1.41)$ & $0.215 * * *(5.02)$ \\
Industry fixed effect & $0.716 * * *(8.33)$ & $0.532 * * *(5.56)$ & $1.027 *(6.48)$ \\
Quarter fixed effect & Included & Included & Included \\
Province fixed effect & Included & Included & Included \\
Adjusted $\mathrm{R}^{2}$ & Included & Included & Included \\
\hline
\end{tabular}

\footnotetext{
${ }^{6}$ Source access: http://finance.sina.com.cn/chanjing/cyxw/20120904/110513040308.shtml
} 


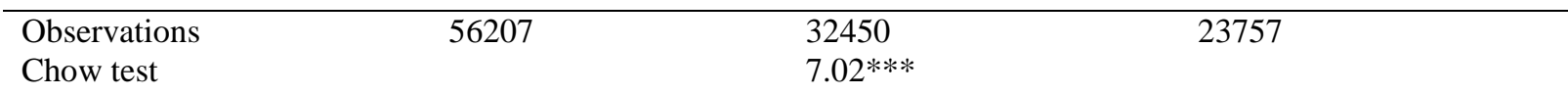

The dependent variable is investment growth. Investment expenditure is defined as the ratio of net capital expenditure to total assets. Stimulus is a dummy variable, equal to 1 for firm-quarter observations falling in the post-stimulus period and 0 otherwise. RET is measured as the log of 1 plus industry stock return. Leverage is the ratio of bank loans to total assets. Income is the ratio of internal cash flow to total assets. Size is the log of firm total assets. Sale is the ratio of sales to total assets. Tangibility is the ratio of a firm's tangible assets to total assets. The Chow test reports the significance of the difference in the coefficients on the Stimulus*RET between SOEs and non-SOEs. The T-statistics are in parentheses and computed using the robust standard error clustered by firm; * **, and *** indicate the significance levels at the $10 \%, 5 \%$, and $1 \%$, respectively.

\subsection{Heterogeneity of bank lending and firm investment decisions}

Analysis so far has shown that stimulus package affects bank lending and firm investment decisions which are significant for SOEs. In this section, we move further to explore cross sectional variations of the effect of the stimulus package on bank lending and firm investment decisions.

\subsubsection{More and less favoured industries}

Firms in our sample operate in different industries and we divide these industries into two groups with different levels of government-injected capital, namely industries more or less favoured by government. In particular, more favoured industries refer to industries where stimulus package-related bank loans are injected, including Construction, Technology, Culture and Conglomerate. Empirically, we re-estimate our main regressions for both industry groups for SOEs and non-SOEs, and the results are reported in Table 9.

In Panel A of Table 9, we report the estimation of bank lending decision regression. Across four specifications, we observe that the estimated coefficients on $R O S$ are all positive and statistically significant, which is consistent with the results from previous tables. As for the Stimulus variable, we find that the estimated coefficients are positive and statistically significant for SOEs and non-SOEs from more favoured industries. This is consistent with our argument that average bank loans increase more significantly for SOEs and non-SOEs from more favoured industries. An interesting finding is that average bank loans decrease for non-SOEs from less favoured industries after the introduction of the economic stimulus package. In particular, the estimated coefficient on Stimulus is -0.027 , significant at the $10 \%$ level ( $\mathrm{t}$-value is -1.84). The variable of interest to us is Stimulus*ROS. Consistent with our predictions, bank lending is less responsive to firm profitability after the introduction of the economic stimulus package, which is more pronounced for SOEs and non-SOEs from more favoured industries.

Table 9. Effect of the economic stimulus package across industries

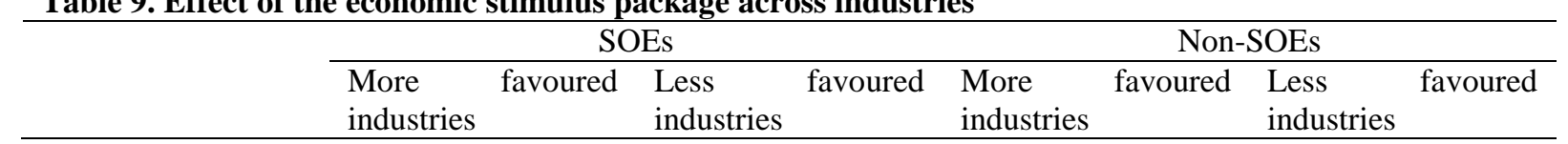




\begin{tabular}{|c|c|c|c|c|}
\hline Stimulus & $0.024 * * *(3.65)$ & $0.016 * * *(4.71)$ & $0.017 * *(2.60)$ & $-0.027 *(-1.84)$ \\
\hline Stimulus*ROS & $-0.009 * *(-1.97)$ & $-0.006 *(-1.68)$ & $-0.002 * *(-2.18)$ & $-0.002(-0.11)$ \\
\hline ROS & $0.018 * *(2.27)$ & $0.017 * * *(5.53)$ & $0.011 * * *(3.52)$ & $0.008 * *(2.62)$ \\
\hline
\end{tabular}

Control variables include Tobin's $Q$, firm size, tangible assets, political connection, board size, independent director, industry, quarter and province fixed effects

$\begin{array}{lllll}\text { Adjusted } \mathrm{R}^{2} & 0.26 & 0.16 & 0.45 & 0.24 \\ \text { Observations } & 10839 & 21611 & 7910 & 15847 \\ \text { Chow test } & 2.28 & & 4.55^{* *} & \end{array}$

Panel B: Dependent variable is investment growth

\begin{tabular}{lllll}
\hline Stimulus & $0.158 * *(2.49)$ & $0.048 * * *(3.43)$ & $0.077 * * *(2.69)$ & $0.043(1.10)$ \\
Stimulus*RET & $-0.085 * * *(-2.58)$ & $-0.027 * * *(-2.91)$ & $-0.105 *(-1.91)$ & $-0.018(-1.26)$ \\
RET & $0.003 * * *(3.37)$ & $0.020 * * *(3.07)$ & $0.056 *(1.72)$ & $0.027 * *(3.74)$
\end{tabular}

Control variables include leverage, income, firm size, sales growth, tangible assets, industry, quarter and province fixed effects

$\begin{array}{lllll}\text { Adjusted R } \mathrm{R}^{2} & 0.41 & 0.37 & 0.37 & 0.38 \\ \text { Observations } & 10839 & 21611 & 7910 & 15847 \\ \text { Chow test } & 0.77 & & 2.89 * & \end{array}$

This table reports the results of estimation of equation (2) and (3) for SOEs and non-SOEs from more and less favoured industries. Panels A and B represent bank lending and firm investment decisions regressions respectively and all the variables are defined as in previous tables. In Panels A and B, the Chow tests report the significance of the difference in the coefficients on the Stimulus*ROS and Stimulus*RET between firms from more and less favoured industries for both SOEs and non-SOEs. The T-statistics are in parentheses and computed using the robust standard error clustered by firm; *, **, and *** indicate the significance levels at the $10 \%, 5 \%$, and $1 \%$, respectively.

In Panel B of Table 9, we report the investment decision estimations. From the results, we observe that the average investment growth is significantly higher after the introduction of the economic stimulus package, which is economically significant for SOEs from both more and less favoured industries (t-values are 2.49 and 3.43 for the Stimulus in columns 1 and 2, respectively), and significant at the $1 \%$ level for non-SOEs only from the more favoured industries (t-value is 2.69 for Stimulus in column 3), while it is insignificant for non-SOEs from less favoured industries. Again, the variable of interest is the interaction term Stimulus*RET. Specifically, the estimated coefficients on this interaction are significantly negative for SOEs from both more and less favoured industries (columns 1 and 2) and nonSOEs from more favoured industries (column 3), indicating that investment expenditure is less responsive to investment opportunities after the introduction of the economic stimulus package for these firms. For non-SOEs from less favoured industries, the estimated coefficient on Stimulus*RET is insignificant, though negative, indicating that the investment decision is not affected by the economic stimulus package. Another interesting observation is that with the implementation of the stimulus package, the average investment growth is increased for non-SOEs from more favoured industries while insignificant for non-SOEs from less favoured industries, confirming the argument that non-SOEs contract from the less favoured industries due to lack of funds. 


\subsubsection{More and less favoured regions}

In this section, we conduct analysis regarding the influence of the economic stimulus package across regions. In particular, we divide our sample into two groups. One includes regions whose stimulus plans are above the median level of the local government stimulus plans (more favoured regions) and the rest are included in the other group (less favoured regions). In Section 2.1, we have summarised the stimulus plans for 24 local provincial governments which explicitly announced the amount of capital injected, while the remaining seven local governments did not specify the exact amount of capital injected. Thus, to divide our total sample into two groups of more favoured and less favoured regions, we choose the 15 top-ranked provinces as the more favoured regions and other provinces as the less favoured regions ${ }^{7}$. Consistent with the structure in Table 9, we report the estimation results for both more favoured regions and less favoured regions and for both SOEs and non-SOEs in Table 10.

Panels A and B present the bank lending and firm investment decisions regressions respectively. Not surprisingly, we observe that the average increase in total bank loans and investment growth are significantly higher for SOEs and non-SOEs from more favoured regions. In addition, the results also show that the relationship between bank loans and firm profitability and between firm investment expenditures and investment opportunities become weaker after the introduction of the stimulus package, which are significant for SOEs and non-SOEs from more favoured regions.

Overall, all of these results based on industrial and regional heterogeneities are consistent with our main hypothesis H3 that the supply side forces, namely the bank loan supply shock, shape bank lending behaviour and firm investment policies. Moreover, these effects are significant for SOEs, and for non-SOEs from more favoured industries and regions.

Table 10. Effect of the economic stimulus package across regions

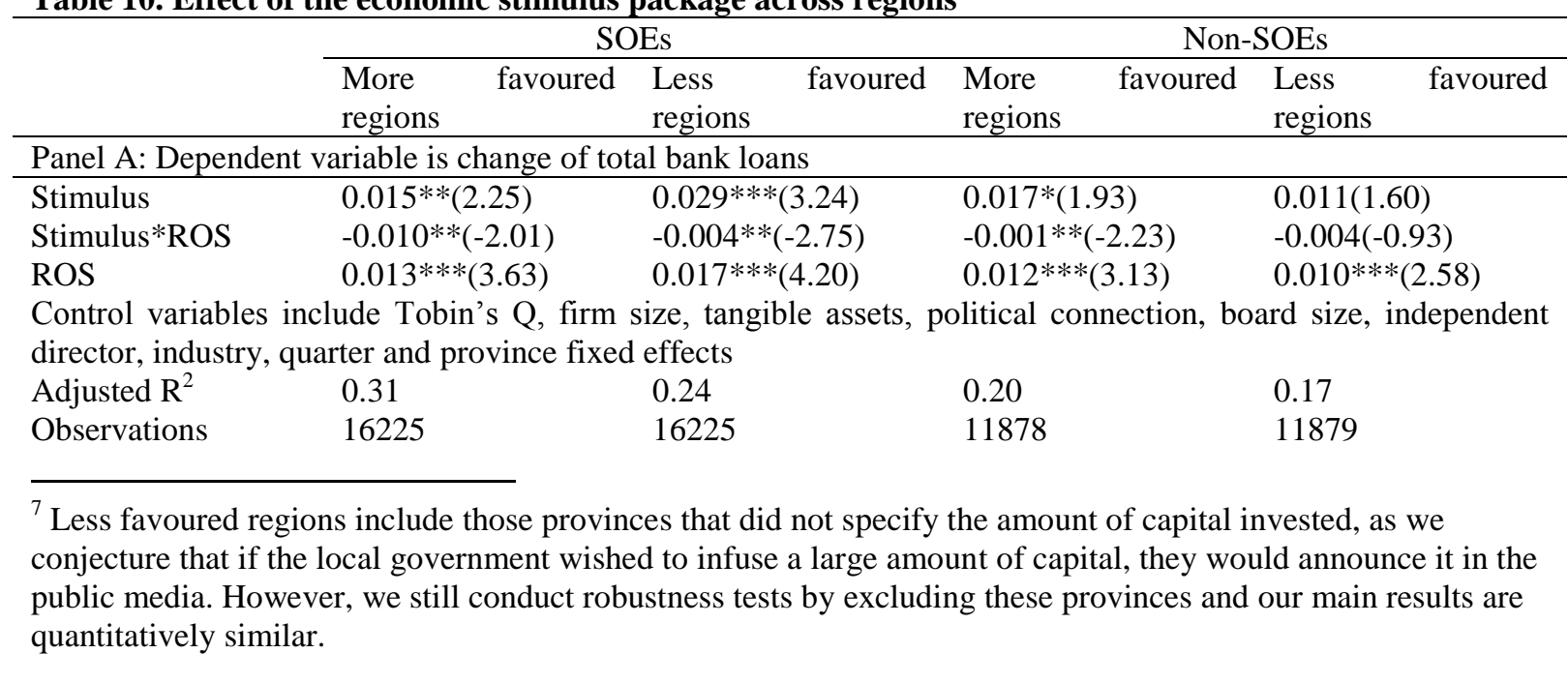


Chow test

0.50

$5.02 * *$

Panel B: Dependent variable is investment growth

$\begin{array}{lllll}\text { Stimulus } & 0.083 * * *(3.46) & 0.034 * *(2.98) & 0.170 * * *(6.30) & 0.010(0.56) \\ \text { Stimulus*RET } & -0.043 * *(-1.98) & -0.017 *(-1.72) & -0.052 * *(-1.98) & -0.013(-0.51) \\ \text { RET } & 0.027 * * *(2.16) & 0.024 * *(2.12) & 0.048 * * *(2.95) & 0.025 * *(2.65)\end{array}$

Control variables include leverage, income, firm size, sales growth, tangible assets, industry, quarter and province fixed effects

$\begin{array}{lllll}\text { Adjusted } \mathrm{R}^{2} & 0.37 & 0.41 & 0.37 & 0.38 \\ \text { Observations } & 16225 & 16225 & 11878 & 11879\end{array}$

Chow test $2.55 \quad 5.25^{* *}$

This table reports the results of estimation of equations (2) and (3) for SOEs and non-SOEs from more and less favoured regions. Panels A and B represent bank lending and firm investment decisions regression respectively and all the variables are defined as in previous tables. In Panels A and B, the Chow tests report the significance of the difference in the coefficients on the Stimulus $* R O S$ and Stimulus*RET between firms from more and less favoured regions for both SOEs and non-SOEs. The T-statistics are in parentheses and computed using the robust standard error clustered by firm; ***, and *** indicate the significance levels at the $10 \%, 5 \%$, and $1 \%$, respectively.

\subsubsection{Firms with and without political connections}

In this section, we provide empirical evidence on how bank lending and firm investment decisions respond to the economic stimulus package for both SOEs and non-SOEs with and without political connections. The results are reported in Table 11, and panels A and B present the results of bank lending and firm investment decision regressions. In the first three columns, we observe that our previous findings hold for SOEs and non-SOEs with political connections. Overall, our findings from Table 11 confirm our hypothesis $\mathrm{H} 4$ that the influences of the economic stimulus package on bank lending and firm investment decisions are significant for non-SOEs with political connections, while they do not differ significantly for SOEs with and without political connections.

Table 11. Effect of the economic stimulus package across firms with and without political connections

\begin{tabular}{|c|c|c|c|c|}
\hline & \multicolumn{2}{|c|}{ SOEs } & \multicolumn{2}{|c|}{ Non-SOEs } \\
\hline & $\begin{array}{l}\text { Political } \\
\text { connections }\end{array}$ & $\begin{array}{l}\text { No political } \\
\text { connections }\end{array}$ & $\begin{array}{l}\text { Political } \\
\text { connections }\end{array}$ & $\begin{array}{l}\text { No political } \\
\text { connections }\end{array}$ \\
\hline \multicolumn{5}{|c|}{ Panel A: Dependent variable is change of total bank loans } \\
\hline Stimulus & $0.035 *(1.91)$ & $0.018 * * *(4.36)$ & $0.017 * *(2.44)$ & $-0.003(-0.28)$ \\
\hline Stimulus*ROS & $-0.004 * *(-2.55)$ & $-0.005 *(-1.94)$ & $-0.002 * *(-2.39)$ & $-0.006(-1.04)$ \\
\hline ROS & $0.015 * * *(2.74)$ & $0.016 * * *(3.43)$ & $0.010 * * *(2.78)$ & $0.018 * *(2.50)$ \\
\hline \multicolumn{5}{|c|}{$\begin{array}{l}\text { Control variables include Tobin's Q, firm size, tangible assets, board size, independent director, industry, } \\
\text { quarter and province fixed effects }\end{array}$} \\
\hline Adjusted $\mathrm{R}^{2}$ & 0.18 & 0.33 & 0.12 & 0.26 \\
\hline Observations & 8762 & 23688 & 8552 & 15205 \\
\hline Chow test & 1.00 & & $4.53 * *$ & \\
\hline \multicolumn{5}{|c|}{ Panel B: Dependent variable is investment growth } \\
\hline Stimulus & $0.085 * * *(3.67)$ & $0.040 * *(2.01)$ & $0.095 * * *(4.77)$ & $0.033(1.29)$ \\
\hline Stimulus*RET & $-0.031 * *(-2.08)$ & $-0.010 * *(-2.55)$ & $-0.033 *(-1.80)$ & $-0.010(-1.20)$ \\
\hline RET & $0.030 * * *(3.68)$ & $0.001 *(1.85)$ & $0.041 * * *(2.91)$ & $0.007(0.51)$ \\
\hline \multicolumn{5}{|c|}{$\begin{array}{l}\text { Control variables include leverage, income, firm size, sales growth, tangible assets, industry, quarter and } \\
\text { province fixed effects }\end{array}$} \\
\hline Adjusted $\mathrm{R}^{2}$ & 0.35 & 0.40 & 0.36 & 0.41 \\
\hline Observations & 8762 & 23688 & 8552 & 15205 \\
\hline Chow test & 0.33 & & $3.13 *$ & \\
\hline
\end{tabular}

This table reports the results of estimation of equations (2) and (3) for SOEs and non-SOEs with and without political connections. Panels A and B represent bank lending and firm investment decisions regressions 
respectively and all the variables are defined as in previous tables. In Panels A and B, the Chow tests report the significance of the difference in the coefficients on the Stimulus*ROS and Stimulus*RET between firms with and without political connections for both SOEs and non-SOEs. The T-statistics are in parentheses and computed using the robust standard error clustered by firm; *, **, and *** indicate the significance levels at the $10 \%, 5 \%$, and $1 \%$, respectively.

\subsection{Additional analysis}

In this section, we conduct a set of additional analysis to further support our main arguments. The first analysis relates to the heterogeneity within SOEs from the points of views of regional corruption levels and SOE ultimate owner types. The second analysis focuses on the market reactions towards the announcement of stimulus package. The third analysis aims to explore the heterogeneity of bank lending decisions based on lender types.

\subsubsection{The influence of stimulus package for SOEs in regions with different levels of corruption and different ultimate owners}

Previous analysis has shown that there is no significant variation in government bank lending towards SOEs. Nevertheless, the influence of stimulus package on SOEs may not be homogeneous. This subsection aims to provide some additional evidence to examine the heterogeneity of bank lending and firm investment decisions for SOEs from the perspectives of regional corruption level and SOE ultimate owner types.

Using a sample of banks from 56 countries, Chen et al. (2014) document that in countries with low corruption, government bank lending is more efficient, which can improve bank performance and stabilize the economy during financial crises, while they observe the opposite phenomenon in countries with high corruption. In their spirit, we exploit the variations in the level of regional corruption in China to test whether, and to what extent, the regional corruption levels have an impact on government bank lending towards SOEs. In particular in regions with high corruption, SOE managers are likely to collude with managers of state-owned banks, which leads to the pursuit of empire-building and higher agency costs, due to insufficient monitoring by the state controlling shareholders (Firth et al., 2008). Thus, it is expected that the influence of the stimulus package on bank lending and firm investment decisions will be more significant for SOEs located in regions with high corruption.

To conduct the regression analysis, we first construct a corruption index to differentiate regions of high and low corruption, and assign regions to the high corruption category if their corruption index is above the median level of the corruption index for a given year ${ }^{8}$. Then, we

\footnotetext{
${ }^{8}$ To construct the regional corruption index, we collect the following information for each province in each year during our sample from the China Procuratorial Yearbook. We first count the number of duty crime cases, and then we count the number of government officials involved in these cases and the total number of government
} 
divide our sample firms into two groups based on whether they are located in regions of high or low corruption, and estimate our main regressions for each group. Table 12 reports the results and our interest is in the interaction terms (Stimulus*ROS and Stimulus*RET). Consistent with our predictions, we observe that the coefficients of these interaction terms are more significant and have greater magnitude for SOEs located in the regions of high corruption. This finding is consistent with the argument of Chen et al. (2014) that government bank lending is less efficient in areas of high corruption.

Table 12 Effect of the economic stimulus package in regions with high and low corruption (SOE sample)

\begin{tabular}{lcl}
\hline & High corruption regions & Low corruption r \\
\hline Panel A: Dependent variable is change of total bank loans & \\
\hline Stimulus & $0.016^{* * *(3.42)}$ & $0.023^{* *(2.16)}$ \\
Stimulus*ROS & $-0.007 * *(-2.28)$ & $-0.003(-0.60)$ \\
ROS & $0.015^{* * *(4.05)}$ & $0.018 * *(4.23)$
\end{tabular}

Control variables include Tobin's Q, firm size, tangible assets, political connection, board size, independent director, industry, quarter and province fixed effects.
Adjusted R ${ }^{2}$
0.38
0.26

Observations

16225

16225

Chow test

$5.25 * *$

Panel B: Dependent variable is investment growth

\begin{tabular}{lll}
\hline Stimulus & $0.087 * * *(2.87)$ & $0.053 * * *(3.08)$ \\
Stimulus*RET & $-0.056 *(-2.44)$ & $-0.023(-1.23)$ \\
RET & $0.032 * *(1.96)$ & $0.023 * * *(2.77)$
\end{tabular}

Control variables include leverage, income, firm size, sales growth, tangible assets, industry, quarter and province fixed effects.

$\begin{array}{lll}\text { Adjusted } \mathrm{R}^{2} & 0.38 & 0.38 \\ \text { Observations } & 16225 & 16225 \\ \text { Chow test } & 4.01 * * & \end{array}$

This table reports the results of estimation of equations (2) and (3) for SOEs from high and low corruption regions. Panels A and B represent bank lending and firm investment decisions regressions respectively and all the variables are defined as in previous tables. In Panels A and B, the Chow tests report the significance of the difference in the coefficients on the Stimulus*ROS and Stimulus*RET between firms from high and low corruption regions. The T-statistics are in parentheses and computed using the robust standard error clustered by firm; *, **, and *** indicate the significance levels at the $10 \%, 5 \%$, and $1 \%$, respectively.

In addition, the ultimate owner of SOEs can be either the central government or a local government, which may also alter the influence of stimulus package, because the central government and local governments have different objectives for retaining ownership in SOEs. Specifically, in the case of central SOEs, the aim is to maintain control over key industries and guarantee the safety of the national economy, while in case of local SOEs, the aim is to increase local GDP and reduce local unemployment (Jin et al., 2005). Wu et al. (2012) argue that compared with central SOEs, local SOEs are subject to severe government intervention. Wang et al. (2008) and Chen et al. (2009) provide empirical evidence to support the argument that central SOEs and local SOEs have different incentives. In the light of this, we repeat the

officials. Then, we calculate the corruption index as the ratio of corrupt officials to total officials for each province in each year. 
above analysis for both central and local SOEs to investigate whether the influence of the stimulus package is different for each of these two groups of firms. The results reported in Table 13 show that our previous findings for SOEs are mainly driven by local SOEs, reflected by significant interaction terms in both panels, indicating that the stimulus package influences the bank lending and firm investment decisions of local SOEs relative to central SOEs. This finding is consistent with the previous argument that local SOEs are subject to more severe government intervention.

Table 13 Effect of the economic stimulus package in central SOEs and local SOEs

\begin{tabular}{|c|c|c|}
\hline & Central SOEs & Local SOEs \\
\hline \multicolumn{3}{|c|}{ Panel A: Dependent variable is change of total bank loans } \\
\hline Stimulus & $0.014 * * *(4.17)$ & $0.025 * * *(7.62)$ \\
\hline Stimulus*ROS & $-0.007(-1.07)$ & $-0.004 * *(-2.38)$ \\
\hline ROS & $0.019 * * *(3.52)$ & $0.008 * *(2.84)$ \\
\hline \multicolumn{3}{|c|}{$\begin{array}{l}\text { Control variables include Tobin's } Q \text {, firm size, tangible assets, political connection, board size, independent } \\
\text { director, industry, quarter and province fixed effects. }\end{array}$} \\
\hline Adjusted $\mathrm{R}^{2}$ & 0.27 & 0.26 \\
\hline Observations & 11799 & 20651 \\
\hline Chow test & $4.77 * *$ & \\
\hline \multicolumn{3}{|c|}{ Panel B: Dependent variable is investment growth } \\
\hline Stimulus & $0.085 * * *(5.05)$ & $0.048 * * *(5.66)$ \\
\hline Stimulus*RET & $-0.061 *(-1.90)$ & $-0.024 * *(-2.17)$ \\
\hline RET & $0.033 *(1.89)$ & $0.022 * * *(3.18)$ \\
\hline \multicolumn{3}{|c|}{$\begin{array}{l}\text { Control variables include leverage, income, firm size, sales growth, tangible assets, industry, quarter and } \\
\text { province fixed effects. }\end{array}$} \\
\hline Adjusted $\mathrm{R}^{2}$ & 0.41 & 0.39 \\
\hline Observations & 11799 & 20651 \\
\hline Chow test & $2.93 *$ & \\
\hline \multicolumn{3}{|c|}{$\begin{array}{l}\text { This table reports the results of estimation of equations (2) and (3) for central SOEs and local SOEs. Panels A } \\
\text { and B represent both bank lending and firm investment decisions regressions and all the variables are defined as } \\
\text { in previous tables. In Panels A and B, the Chow tests report the significance of the difference in the coefficients } \\
\text { on the Stimulus*ROS and Stimulus*RET between central SOEs and local SOEs. The T-statistics are in } \\
\text { parentheses and computed using the robust standard error clustered by firm; *, **, and *** indicate the } \\
\text { significance levels at the } 10 \%, 5 \% \text {, and } 1 \% \text {, respectively. }\end{array}$} \\
\hline
\end{tabular}

\subsubsection{Market reaction to the announcement of the economic stimulus package}

Analyses so far have shown that, from the firms' perspective, the influence of the stimulus package varies according to the ownership structure and institutional environment. In this section, we examine the influence of the stimulus package from the investors' perspective. The purpose of this examination is to see whether investors in the secondary market are able to identify the value implications of the stimulus package announcement. If the stimulus package is likely to influence bank lending and firm investment decisions as we documented before, investors will discount this announcement. Specifically, the announcement effect is measured by the market-adjusted cumulative abnormal returns (CARs) around the announcement using the market-adjusted excess return model. We choose two 
days in the event window $(0,+1)$, and 230 days as the estimation window $(-240,-10)$. Our CAR calculation is consistent with the method applied by Huang et al. (2012).

Empirically, we regress CARs against ownership structure and institutional environment proxies and report the results in Table 14. All independent variables are from the quarter before the announcement, following Huang et al. (2012). In column 1, the coefficient of SOE is -0.007 and statistically significant at the $5 \%$ level (t-value is -1.97 ), indicating that investors feel pessimistic about the stimulus package for SOEs, which is consistent with our previous findings for SOEs. Columns 2 to 4 report the investor reaction for both SOEs and non-SOEs from different industries or different institutional environments and the results are consistent with our findings in the above subsections. For example in column 2 , the coefficient of Favoured industry dummy is - 0.010 and significant at the 5\% level (t-value is 2.17). This result indicates that for non-SOEs from more favoured industries (when the $S O E$ dummy equals 0 , the coefficient of Favoured industry dummy represents the market reaction to non-SOEs from favoured industries), the stock price within the first day window is $1 \%$ lower than for those non-SOEs from less favoured industries, consistent with our previous findings in Table 9 that the stimulus package influences bank lending and firm investment decisions for non-SOEs from more favoured industries. Overall, the results from the event study are consistent with our previous findings and support our hypotheses.

Table 14 Effects of ownership and institutional environment on CARs around stimulus package announcement

Dependent variable is the two-day CARs around stimulus package announcement

\begin{tabular}{|c|c|c|c|c|}
\hline SOE & $\begin{array}{l}-0.007 * * \\
(-1.97)\end{array}$ & $\begin{array}{l}-0.007 * * \\
(-2.05)\end{array}$ & $\begin{array}{l}-0.009 * \\
(-1.83)\end{array}$ & $\begin{array}{l}-0.007 * \\
(-1.93)\end{array}$ \\
\hline SOE*Favoured industry dummy & & $\begin{array}{l}-0.007 \\
(-0.47)\end{array}$ & & \\
\hline SOE*Favoured region dummy & & & $\begin{array}{l}-0.007 \\
(-1.31)\end{array}$ & \\
\hline SOE*Political connection dummy & & & & $\begin{array}{l}-0.002 \\
(-0.28)\end{array}$ \\
\hline Favoured industry dummy & & $\begin{array}{l}-0.010 * * \\
(-2.17)\end{array}$ & & \\
\hline Favoured region dummy & & & $\begin{array}{l}-0.015 * * * \\
(-3.03)\end{array}$ & \\
\hline Political connection dummy & & & & $\begin{array}{l}-0.005^{*} \\
(-1.73)\end{array}$ \\
\hline \multicolumn{5}{|c|}{$\begin{array}{l}\text { Control variables included in the regressions are return on sales, Tobin's Q, leverage, income, tangible assets, } \\
\text { board size and independent director ratio. }\end{array}$} \\
\hline Adjusted $\mathrm{R}^{2}$ & 0.03 & 0.04 & 0.05 & 0.04 \\
\hline Observations & 1297 & 1297 & 1297 & 1297 \\
\hline
\end{tabular}

This table reports the results of the market reaction to the announcement of the stimulus package for firms with different ownership structure from different industries or institutional environments. The dependent variable is the two-day CARs around the announcement of the stimulus package. The T-statistics are in parentheses and computed using the robust standard error clustered by firm; *, **, and *** indicate the significance levels at the $10 \%, 5 \%$, and $1 \%$, respectively. 


\subsubsection{The influence of stimulus package based on lender types}

In this section, we divide banks into different groups and examine how bank ownership heterogeneities affect their lending decisions. In particular, we divide all banks that extend credit to our sample firms into the following four groups, namely, government-owned banks (this group includes the big five banks and three policy banks), city commercial banks, jointequity banks (this group includes joint-equity commercial banks and their affiliated institutions), and non-state owned bank (this group includes foreign banks and other non-state owned joint-equity banks). Two classifications need to be noticed. First, the Communication Bank is categorized as one of big five government-owned banks. Second, four joint-equity banks (Minsheng bank, Pingan bank, Zheshang bank and Hengfeng banks) are classified as non-state owned banks due to their largest shareholder is not the Chinese government, though the nomination of Chairman needs to be approved by the China Banking Regulatory Commission (see Appendix 1 for the guideline of our classification). Then we estimate our main regression for each group and report the results in Table 15. In this analysis, we apply the bank loan level data for regression estimation. Initially, we are able to collect 2,531 bank loans. Then we delete 83 loans with missing information on the loans, 408 loans due to unclassified bank types, and finally have 2,040 loans for analysis.

From Table 15, we observe that the average newly granted bank loans becomes significantly larger after the introduction of the economic stimulus package for governmentowned bank and joint-equity bank groups, while significantly smaller for non-state owned bank group. This result is consistent with the evidence from developed markets that private bank lending decreases significantly during the financial crisis period (Leary, 2009; Lemmon and Roberts, 2010; Lin et al., 2014). These results confirm our previous argument that direct government lending is implemented through the state-owned banking system, while other creditor lending declines. We also observe that the estimated coefficients of ROS are only statistically significant in the city commercial banks and non-state owned banks groups, indicating that commercial judgement is only applied by city commercial banks and non-state owned banks. Most importantly, we find that the interaction terms show significantly negative coefficients for government-owned bank and joint-equity bank groups, suggesting that lending decisions of government owned banks and joint-equity banks have been significantly influenced by the economic stimulus package. In addition, the bank lending decision is enhanced for non-state owned banks, reflected by a positive though insignificant estimated coefficient on the Stimulus*ROS term.

Table 15 Effect of the economic stimulus package on bank lending decisions by bank types 


\begin{tabular}{|c|c|c|c|c|c|}
\hline \multirow[t]{2}{*}{ Dependent variable } & \multicolumn{5}{|c|}{ Newly granted bank loans scaled by total assets } \\
\hline & $\begin{array}{l}\text { 1.Government } \\
\text { owned banks }\end{array}$ & $\begin{array}{l}\text { 2.City } \\
\text { banks }\end{array}$ & commercial & 3.Joint-equity banks & $\begin{array}{l}\text { 4.Non-state } \\
\text { owned banks }\end{array}$ \\
\hline Stimulus & $\begin{array}{l}0.031^{* * * *} \\
(2.89)\end{array}$ & $\begin{array}{l}-0.008 \\
(-1.05)\end{array}$ & & $\begin{array}{l}0.005^{*} \\
(1.94)\end{array}$ & $\begin{array}{l}-0.033 * * * \\
(-2.60)\end{array}$ \\
\hline Stimulus*ROS & $\begin{array}{l}-0.018 * * * \\
(-2.63)\end{array}$ & $\begin{array}{l}-0.025 \\
(-0.80)\end{array}$ & & $\begin{array}{l}-0.080 * * * \\
(-2.86)\end{array}$ & $\begin{array}{l}0.068 \\
(1.44)\end{array}$ \\
\hline ROS & $\begin{array}{l}-0.031 \\
(-1.19)\end{array}$ & $\begin{array}{l}0.034^{* *} \\
(2.43)\end{array}$ & & $\begin{array}{l}0.010 \\
(0.78)\end{array}$ & $\begin{array}{l}0.026^{* *} \\
(1.98)\end{array}$ \\
\hline
\end{tabular}

Control variables include Tobin's Q, firm size, tangible assets, political connection, board size, independent director ratio, industry and year fixed effects

\begin{tabular}{llllllc} 
Adjusted $\mathrm{R}^{2}$ & 0.16 & \multicolumn{2}{c}{0.09} & & 0.19 & \multicolumn{2}{c}{0.25} \\
Observation & 1105 & \multicolumn{2}{c}{177} & & 518 & 240 \\
Chow test & 1 vs 2 & 1 vs 3 & 1 vs 4 & 2 vs 3 & 2 vs 4 & 3 vs 4 \\
& $5.13^{* *}$ & 0.86 & $5.78^{* *}$ & $5.66^{* *}$ & 1.60 & $6.65^{* * *}$ \\
\hline
\end{tabular}

This table reports the results of bank lending decisions using bank loan level data by dividing our total sample into four groups based on lending institutions. The Chow test reports the significance of the difference in the coefficients on the Stimulus*ROS between each pairs of sub-samples. T-statistics are in parentheses and computed using the robust standard error clustered by the firm. *, **and *** indicate significance at the $10 \%, 5 \%$ and $1 \%$ levels, respectively.

\subsection{Robustness tests}

\subsubsection{Endogeneity}

One concern about our results on the influence of the stimulus package on bank lending decisions and firm investment efficiencies is endogeneity, due to endogenous regressors and unobserved heterogeneities. For example, in our bank lending decision model, firm profitability is likely to be determined by other independent variables, so that it is endogenously determined. In addition in our investment decision model, investment opportunities are also likely to be correlated with leverage. To address the endogeneity of regressors, we apply the first-difference Generalized Method of Moments (GMM) as an alternative to check the robustness of our results. The use of GMM can also account for unobserved heterogeneity and time-invariant firm characteristics, as developed by Arellano and Bond (1991). To apply this method, we first add a one period lag of dependent variable on the right hand to account for any possible dynamic endogeneity (Arellano and Bond, 1991). Then, we assume all our independent variables, except quarter dummies, are potentially endogenous, which means that there may be some forms of persistence in our independent variables such as ROS and RET. Thus we use two and three period lags of all potential endogenous independent variables as instruments in our regression models.

Table 16 reports the estimation results of both bank lending and firm investment decisions equations. As we use the differenced GMM with the lagged dependent variables as the explanatory variables, it is noted that the observations of both equations are smaller than the full sample. In addition, as we use different independent variables in both equations, the 
observations for both regressions are slightly different. The signs of estimated coefficients of our key variables are the same as those in previous tables, which confirms the robustness of our main findings. In addition, we observe that, after controlling for the potential endogeneity of all regressors, the magnitudes of coefficients are even larger. The Hansen tests (p-values) are both larger than 0.1 , indicating that we cannot reject the null hypothesis that instrumental variables are exogenous. We also report the first and second-order auto-correlation tests. These results suggest that residuals are correlated at the first order but not at the second order.

Table 16 Bank lending and firm investment decisions equations (GMM estimation)

\begin{tabular}{|c|c|c|}
\hline 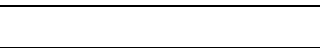 & Bank lending decisions equation & Firm investment decisions equation \\
\hline Stimulus & $0.605 * * *(2.66)$ & $0.218^{* *}(2.42)$ \\
\hline Stimulus*ROS & $-0.117 * * *(-2.65)$ & \\
\hline ROS & $0.114 * * *(4.47)$ & \\
\hline Stimulus*RET & & $-0.386 * * *(-2.61)$ \\
\hline RET & & $0.107 * *(2.27)$ \\
\hline \multicolumn{3}{|c|}{$\begin{array}{l}\text { Lagged dependent variable and other control variables in equation (2) and (3) are also included in each } \\
\text { regression. }\end{array}$} \\
\hline Hansen test (p-value) & 0.46 & 0.58 \\
\hline AR (1) (p-value) & 0.00 & 0.01 \\
\hline AR (2) (p-value) & 0.74 & 0.81 \\
\hline Observations & 51437 & 52240 \\
\hline
\end{tabular}

\subsubsection{Other robustness tests}

To complement previous analysis from firms' perspective, we conduct event study to examine the influence of stimulus package on bank lending and firm investment decisions from investors' perspective. To do so, we compare the CARs for bank loans and mergers and acquisitions announcements before and after the implementation of stimulus package. The unreported results show that CARs for bank loans and mergers and acquisitions announcements are significantly lower for SOEs after the introduction of the stimulus package, which is consistent with our previous arguments.

In the prior analysis we have used the Stimulus dummy variable to indicate the economic stimulus package period. One concern is that it may be a bit too noisy because it may also incorporate information other than the government stimulus package implemented in China. Moreover, using the dummy variable can only reflect the static process, which ignores the dynamic trend. In this sense, we create an alternative proxy for the economic stimulus package policy, which is a continuous variable defined as the ratio of quarterly change in bank loan supply to the bank loan supply of the last quarter. 
Our next robustness test relates to the identification of bank loan supply expansion periods. Shen et al. (2014) define the period between the fourth quarter of 2008 and fourth quarter of 2010 as the capital expansion period. In their spirit, we conduct two additional regression analysis by (1) re-defining Stimulus dummy to be consistent with Shen et al. (2014), and (2) deleting the period between the fourth quarter of 2008 and fourth quarter of 2010 from our sample.

We further conduct robustness check by applying alternative measurement of investment opportunities in our bank loan equations (1) and (2). As argued by Almeida and Campello (2007), the information about investment opportunities is captured by other variables such as cash flows if the firm is seen as financially constrained, and in this sense Tobin's Q is a comparatively poorer proxy for investment opportunities ${ }^{9}$. To address this concern, we use the growth rate of sales level as an alternative proxy for investment opportunities following Nash et al. (2003), and re-estimate our bank loan equations. Additionally, we also repeat the bank loan equation estimation using the bank loan level data for robustness check. All of above robustness test results remain quantitatively similar to the main results reported in previous tables, which confirm that our main findings are robust for alternative measurements. To save the space, we do not report the results of this section but they are available on request.

\section{Conclusion}

This paper provides evidence of how the supply-side shock of bank loans affects bank lending and firm investment decisions. The implementation of the Chinese economic stimulus package and the related expansion of bank loan supply are used as a laboratory to test our hypotheses. Primarily, we find that the implementation of the stimulus package after the financial tsunami enables both SOEs and non-SOEs to gain better access to bank loans and encourage them to make more investment, which is helpful for economic recovery. However, the economic stimulus package results in weaker relationships between bank loans and firm profitability and between investment expenditure and investment opportunities, especially in local SOEs, SOEs from high corruption regions, non-SOEs from more favoured industries and regions, and non-SOEs with political connections. Our main findings are robust to corrections for endogeneity and alternative measurements.

Overall, our findings suggest that, contrary to developed countries such as Japan, where government direct lending effectively corrects the inefficiency of credit market freezes and has a beneficial effect at the firm level (Lin et al., 2014), the increased bank loan supply and

\footnotetext{
${ }^{9} \mathrm{We}$ appreciate the associate editor's comment for pointing out this issue.
} 
government lending in China, where the government owns SOEs as well as a majority of banks, are mainly allocated to SOEs rather than non-SOEs. Moreover, SOE investments are less related to investment opportunities because newly granted loans are less connected with firm profitability. This being the case, we reveal the economic consequence of stimulus packages in emerging markets.

\section{Appendix 1. Classification of bank types}

\begin{tabular}{ll}
\hline Government-owned banks & These include Industrial and Commercial Bank of China, China \\
& Construction Bank, Agriculture Bank of China, Bank of China, \\
& Communication Bank, Agricultural Development Bank of China (1994), \\
& The Export-Import Bank of China (1994), China Development Bank \\
& $(1994)$. \\
& These include 136 commercial banks at city levels. The top 10 city \\
City commercial banks & Agriculture Commercial Bank, Chongqing Agriculture Commercial Bank, \\
& Shanghai Agriculture Commercial Bank, Nanjing Bank, Guangzhou \\
& Agriculture Commercial Bank, Ningbo Bank, Hongzhou Bank, and Tianjin \\
& Bank. \\
& These include China Merchants Bank (1988), China Citic Bank (1988), \\
& China Everbright Bank (1992), Huaxia Bank (1992), Industrial Bank \\
Joint-equity banks & (1988), Shanghai Pudong Development Bank (1992), China Guangfa Bank \\
& These Bnclude foreign banks operating on the mainland of China and non- \\
& state owned banks whose largest shareholder is not Chinese government. \\
Which include Beijing Bank and four joint-equity banks (Minsheng bank, \\
Pingan bank, Zheshang bank and Hengfeng banks).
\end{tabular}

Figures in brackets are the year of the establishment of banks. 


\section{References}

Agrawal, A., Knoeber, C., 2001. Do some outside directors play a political role? Journal of Law and Economics 44(1), 179-198.

Allen, F., Qian, J., Qian, M., 2005. Law, finance, and economic growth in China. Journal of Financial Economics 77, 57-116.

Almeida, H., Campello, M., 2007. Financial Constraints, Asset Tangibility, and Corporate Investment. Review of Financial Studies 20(5), 1429-1460.

Arellano, M., Bond, S., 1991. Some tests of specification for panel data: Monte Carlo evidence and an application to employment equations. Review of Economics Studies 58(2), 277-297.

Bebchuk, L., Goldstein, I., 2011. Self-fulfilling credit market freezes. Review of Financial Studies 24(11), 3519-3555.

Bertrand, M., Schoar, A., Thesmar, D., 2007. Banking deregulation and industry structure: evidence from the French banking reforms of 1985. Journal of Finance 62(2), 597-628.

Brandt, L. and Li, H., 2003. Bank discrimination in transition economies: ideology, information, and incentives? Journal of comparative economics, 31, 387-413.

Bushman, M. R., Piotroski, J. D., Smith, A. J., 2011. Capital allocation and timely accounting recognition of economic losses. Journal of Business Finance Accounting 38(1), 1-33.

Cai, F., Wang, D., Zhang, H., 2010. Employment Effectiveness of China's Economic Stimulus Package. China and World Economy 18(1), 34-46.

Chen, G., Firth, M., Xu, L., 2009. Does the type of ownership control matter? Evidence from China's listed companies. Journal of Banking and Finance 33, 171-181.

Chen. S, Sun, Z., Tang, S., Wu, D., 2011. Government intervention and investment efficiency: Evidence from China. Journal of Corporate Finance 17, 259-271.

Chen, Y., Liu, M., Su, J., 2013. Greasing the wheels of bank lending: Evidence from private firms in China. Journal of Banking and Finance 37(7), 2533-2545.

Chen, Y., Chen, Y., Hasan, I., Lin, C., 2014. Is there a bright side to government banks? Evidence from the global financial crisis. Working paper.

Claessens, S., Feijen, E., Laeven, L., 2008. Political connections and preferential access to finance: The role of campaign contributions. Journal of Financial Economics 88, 554-580.

Cull, R., Xu, L., 2000. Bureaucrats, state banks, and the efficiency of credit allocation: the experience of Chinese state-owned enterprises. Journal of Comparative Economics 28, 1-41. 
Cull, R., Xu, L., 2003. Who gets credit? The behaviour of bureaucrats and state banks in allocating credit to Chinese state-owned enterprises. Journal of Development Economics 71, 533-559.

Cull, R., Xu, L.C., and Zhu, T., 2009. Formal finance and trade credit during China's transition. Journal of financial intermediation, 18, 173-192.

Deng, Y., Morck, R., Wu, J., Yeung, B., 2014. Monetary and Fiscal Stimuli, Ownership Structure, and China's Housing Market. NBER working paper.

Dewenter, K.L. and Malatesta, P.H., 2001. State-owned and privately owned firms: an empirical analysis of profitability, leverage, and labour intensity. American economic review, 91, 320-334.

Dinc. I., 2005. Politicians and banks: Political influence on government-owned banks in emerging countries. Journal of Financial Economics 77, 453-459.

Duchin, R., Ozbas, O., Sensoy, B., 2010. Costly external finance, corporate investment, and the subprime mortgage credit crisis. Journal of Financial Economics 97, 418-435.

Faccio, M., 2006. Politically Connected Firm. The American Economic Review, 96 (1), 369 $-386$.

Faccio, M., 2010. Differences between politically connected and nonconnected firms: A cross-country analysis. Financial Management 39(3), 905-928.

Fan, J., Wong, T.J., Zhang, T., 2007. Politically connected CEOs, corporate governance, and Post-IPO performance of China's newly partially privatized firms. Journal of Finance Economics 84, 330-357.

Faulkender, M., Petersen, M.A., 2006. Does the source of capital affect capital structure? Review of Financial Studies 19(1), 45-79

Firth, M., Lin, C., Wong, S. M. L., 2008. Leverage and investment under a state-owned bank lending environment: Evidence from China. Journal of Corporate Finance 14, 642-653.

Firth, M., Lin, C., Liu, P., Wong, S. M. L., 2009. Inside the black box: Bank credit allocation in China's private sector. Journal of Banking and Finance 33, 1144-1155.

Firth, M., Malatesta, P. H., Xin, Q., Xu, L., 2012. Corporate investment, government control, and financing channels: Evidence from China's listed companies. Journal of Corporate Finance 18, 433-450.

Giannetti, M., Simonov, A., 2009. On the real effects of bank bailouts: Micro-evidence from Japan. Working paper, Stockholm School of Economics.

Guangxi Daily, 2009. Speeding up the injection of the new bank loans of 200 Billion Yuan. 
Huang, W., Schwienbacher, A., Zhao, S., 2012. When bank loans are bad news: Evidence from market reactions to loan announcements under the risk of expropriation. Journal of International Financial Market, Institutions \& Money 22, 233-252.

Jin, H., Qian, Y., Weingast, B. R., 2005. Regional decentralization and fiscal incentives: federalism Chinese style. Journal of Public Economics 89, 1719-1742.

Kashyap, A., Stein, J., Wilcox, D., 1993. Monetary Policy and Credit Conditions: Evidence from the Composition of External Finance. American Economic Review 83(1), 78-98.

Khwaja, A., Mian, A., 2005. Do lenders favour politically connected firms? Rent provision in an emerging financial market. Quarterly Journal of Economics 120, 1371-1411.

Leary, M., 2009. Bank loan supply, lender choice, and corporate capital structure. Journal of Finance 64(3), 1143-1185.

Lemmon, M., Roberts, M.R., 2010. The response of corporate financing and investment to changes in the supply of credit. Journal of Financial and Quantitative Analysis 45(3), 555587.

Li, K., Yue, H., and Zhao, L., 2009. Ownership, institutions, and capital structure: evidence from China. Journal of comparative economics, 37, 471-490.

Lin, Y., Srinivasan, A., Yamada, T., 2014. The effect of government bank lending: Evidence from the financial crisis in Japan. Working paper.

Modigliani, F., Miller, M., 1958. The cost of capital, corporate finance and the theory of investment. The American Economic Review 48(3), 261-297.

Nash, R., Netter, J., Poulsen, A., 2003. Determinants of contractual relations between shareholders and bondholders: Investment opportunities and restrictive covenants. Journal of Corporate Finance 9, 201-232.

Naughton, B., 2009. Understanding the Chinese stimulus package. China Leadership Monitor $28,1-12$.

Pindado, J., Requejo, I., Torre, C., 2011. Family control and investment-cash flow sensitivity: Empirical evidence from the Euro zone. Journal of Corporate Finance 17, 1389-1409.

Sapienza, P., 2004. The effects of government ownership on bank lending. Journal of Financial Economics 72, 357-384.

Shleifer, A. and Vishny, R.W., 1994. Politicians and firms. Quarterly journal of economics, 109, 995-1025.

Shen, J., Firth, M., Poon, W., 2014. Bank loan supply and corporate capital structure: recent evidence from China, Financial Management Association annual meeting, working paper. 
Titman, S., 2002. The Modigliani and Miller theorem and the integration of financial markets. Financial Management 31, 101-115.

Tong, H., Wei, S.J., 2011. Did unconventional interventions unfreeze the credit market? Some international evidence. Working paper, Columbia University.

Wang, Q., Wong, T.J., Xia, L., 2008. State ownership, the institutional environment, and auditor choice: Evidence from China. Journal of Accounting and Economics 46(1): 112-134.

Wong, C., 2011. The fiscal stimulus programme and public governance issues in China. OECD Journal of Budgeting 11(3), 1-21.

Wu, W., Wu, C., Rui, M., 2012. Ownership and the value of political connections: Evidence from China. European Financial Management 18(4), 695-729.

Zheng, Y., Zhu, Y., 2013. Bank lending incentives and firm investment decisions in China. Journal of Multinational Financial Management 23, 146-165.

Zhu, J., Han, F., Lu, Z., 2010, Do bank connections alleviate financial constraints under industry policy? Evidence from private listed firms in A share market in China. Working paper (in Chinese). 